\title{
Muslim Fundamentalism: Psychological Orientations and Counter-Narratives
}

\author{
Amina Hanif Tarar, Syeda Salma Hasan \\ GC University, Lahore, Pakistan
}

\begin{abstract}
The current study attempted to formulate a conceptualization of Muslim fundamentalism as well as its counter-narratives as grounded in religious experience of Pakistani Muslims. Open ended interviews were conducted with 133 Pakistani Muslim men and women of prominent local religious affiliations. Analysis revealed a grounded theory model of Muslim fundamentalism highlighting cognitive, and social psychological processes involved. Participants saw their religion as a complete code of conduct and inferred various meanings from completeness of Islam as finalized, closed to inquiry as well as rejecting of other cultures and religious traditions. The major inter-related themes of the model were totalitarianism, closed mindedness, binary thinking, hyper-exotericism, ambiguity intolerance, authoritarianism, punitive approach, violent tendencies, labelling, diversity intolerance and paranoia or threat perceiving attitude. The interplay of these factors is discussed in the light of earlier research on fundamentalism. The research also revealed strong counter narratives to fundamentalist stance which formulated the major themes of esoteric religiosity, open mindedness, pluralism, and Islam and civil society. The study carries implications for religious education of Muslims and their socialization with believers of other religious traditions.
\end{abstract}

Keywords: fundamentalism, Islam, binary/contextualized thinking, authoritarianism, exoteric/esoteric religiosity, pluralism, totalitarianism

\section{Introduction}

Fundamentalism is a sensitive term with many social, religious and political debates around it. There have been many attempts to define and understand this complex phenomenon. The term 'fundamentalism' generally has been mostly understood in the context of religion. Religious fundamentalism has been understood as an adherence to the supremacy of some beliefs or some set of religious teachings as containing the basic and essential truth, idealization of past practices to be followed in current times and of those who live up to these standards, and an idea of an essential evil opposing this fundamental truth which is to be fought out (Altemeyer \& Hunsberger, 1992). Other recent models emphasize the supremacy of religious text subjugating other forms of knowledge to it as the root cause of fundamentalism (Hood, Hill, \& Williamson, 2005). Religious fundamentalism is defined most often in relation to modernity and post modernity: for instance, as the form religion has taken when it has become increasingly defensive under assaults by current rationalistic, scientific

Amina Hanif Tarar, Ph.D., Assistant Professor, Department of Psychology, GC University, Lahore, Pakistan.

Syeda Salma Hasan, Ph.D., Professor, Department of Psychology, GC University, Lahore, Pakistan. 
and materialistic zeitgeist and the uncertain, relative and context-dependent ideological circumstances of post modernity (Jost, Conway, Savage, White, \& O’Neill, 2012). It is a religiously based cognitive and affective orientation to the world characterized by protest against the continual change and the ideological orientations of modernity (Antoun, 2001), and a new anchor of identity in an ever changing and highly diffused depersonalized world eroding its prior social relations (Riesebrodt, 1993; 1990). Hogg (2004) observes fundamentalism as a reaction to the uncertainty which promotes a need for cognitive closure and inspires joining of groups and ideologies which are highly authoritarian, hierarchical, rigid, orthodox and contribute to uncertainty reduction. Fundamentalism has also been framed as a response to identity threat posed by modernity to traditional religious values. Bruce (2000) holds fundamentalism as a rational response of traditionally religious people to socio-political changes that threaten their cultural values and their transmission to next generations. Marty and Appleby (1991) also emphasize fundamentalism as being a strategy to preserve a threatened identity amidst the contemporary secular milieu by fortifying it with selective beliefs from a sacred past. Fundamentalism has also been identified as religious militance by 'true believers' attempting against the erosion of their religious community and collective identity (Almond, Appleby, \& Sivan, 2003). Muslim fundamentalism has become increasingly conspicuous with regards to political unrest in the world. Muslim radicalism is on the rise across the globe. This calls for studying what particular understandings of Islam lead to fundamentalist stance. Are there any counter-narratives to fundamentalist stance? The current study is an investigation of psychological processes involved in Muslim fundamentalism and how these processes are grounded in indigenous understanding of Islam. Furthermore, it investigates the inter-relationships of these social psychological processes by which a pattern of Muslim fundamentalism can be understood while attempting to relate the concepts with existing theory on fundamentalism.

\section{Objectives}

1. To investigate the cognitive and psychological mechanisms involved in understanding of and experience of religious faith among Pakistani Muslims.

2. To find out the inter-relationships of these frameworks to generate a model of Muslim fundamentalism grounded in indigenous experience and understanding of Islam.

\section{Method}

\section{Qualitative Design}

Grounded theory was used as most relevant to above queries. Grounded theory "is an inductive, theory-discovery methodology that allows the researcher to develop theoretical account of the general features of a topic while simultaneously grounding the account in empirical observations or data." (Martin \& Turner, 1986, p. 141). Given the wide spectrum of contents of faith among Muslims, grounded theory was chosen for the present study as it provides more freedom to explore data for many lines of inquiry to emerge; consequently, it is useful for providing new insights. Also, since it has ample capacity to account for complex phenomena (Charmaz, 2003), it was expected to conceptually disentangle through systematic steps the complex and multifaceted phenomenon of faith. Another reason for employing grounded theory is the constructivist nature of religious faith itself for which Charmaz (2003) regards grounded theory as suitable. Glaser (2012) holds that free of theoretical constraints, grounded theory helps the researcher to see things as they are. Grounded theory deals with what is happening around a social phenomenon and is thus linked with the process by which it is 
happening (Strauss \& Corbin, 1990). Since the objective here is to know the psychological and social psychological processes that surround faith, grounded theory is expected to fit the objective. Finally, this study is an indigenous exploration of religious faith as occurring in local data. It chooses grounded theory as it has been emphasized as a well-defined process beginning with a description of data to more conceptual comprehension and moves on to theorizing (Patton, 2002).

Grounded theory comes in various versions as original (Glaser \& Strauss, 1967), Glaserian (Glaser, 1978), Straussian, (Strauss \& Corbin, 1990), and a hybrid version of the two and constructivist grounded theory (Charmaz, 2006). However, as Walker and Myrick (2006) observe, despite the theoretical debates around them, Glaserian and Straussian approaches to grounded theory are similar as both adhere to the same basic research process: Gather data, code, compare, categorize, theoretically sample, develop a core category, and generate a theory. Both use coding and constant comparison, ask questions, do theoretical sampling, and write memos in the process of generating theory. Choosing between them hence is a matter of suitability to the research rather than taking a paradigmatic position (Glaser, 2001). The current study, while following the above general principles, adhered to advice by Glaser $(1978 ; 2001)$ to tolerate confusion, trust emerging data without worrying about justification, allow moments of isolation to get deep in data analysis and moments of consultation and discussion, be open to emerging evidence, and to act on the new evidence, be able to conceptualise to derive theory from the data, and finally try to be genuine.

\section{Tool}

Open-ended Interviews were conducted to collect data. Preliminary investigation started off with faith development interview question inquiring about one's concept of a person of mature faith. Since further open ended discussion may lead to their constructions of what is true Islam, the question can serve as a sound opening to the investigation of how Islam is understood and what processes are involved in these reasonings. Further discussion led by participants was purposefully kept open ended so that emerging concepts are grounded in the perceptions, understanding and experience of Muslim religious faith.

Sample. Following the concept of theoretical sampling, approaching sample was thus an ongoing process simultaneous with data collection, coding, comparisons, and accumulation of information to form categories. New participants were contacted on the basis of codings reached in earlier stage. Following "One keeps on collecting data until one receives only already known statements" (Seldén, 2005, p. 124), by the time categories became clear, differentiated and saturated, a total of 133 (62 men and 71 women) participants had been interviewed. Though an effort was made to keep the relative number of men and women and various age groups the same, more equity in age, occupation, religious sect, or other demographics could not be ensured as willingness to participate was a major factor in recruiting people. The demographics of all sample contacted at various stages of the study are as in Table 1.

Table 1

Sample Demographics

\begin{tabular}{|l|l|l|l|}
\hline Men $\mathrm{N}=62(47 \%)$ & & \\
\hline Age range & Occupation & Qualifications & Religious sect \\
\hline Adults & Engineers & B.Sc Engineering 12 & \\
$(20-40$ yrs $) 18$ & (serving \& retired) 20 & M.Sc Engineering 8 & Ahle Sunnah 23 \\
Middle aged & MBBS FCPS 9 & Ahle Hadith 18 \\
(41-60yrs) 23 & Doctor 9 & MBleTashi 12 \\
Old aged & Businessman 11 & MA/M.Sc. 11 & Deobandi 9 \\
\hline
\end{tabular}




\begin{tabular}{|c|c|c|c|}
\hline$(61-80+y r s) 21$ & \begin{tabular}{|l} 
College/retired 3 \\
Managers 5 \\
Madarassa Muallim 4 \\
Office job 6
\end{tabular} & $\begin{array}{l}\text { Muallim course } 4 \\
\text { BA/B.Sc. } 8\end{array}$ & \\
\hline \multicolumn{4}{|l|}{ Women $71(53 \%)$} \\
\hline $\begin{array}{l}\text { Adults } \\
\text { (20-40 yrs) } 23 \\
\text { Middle aged } \\
(41-60 \text { yrs }) 27 \\
\text { Old Age } \\
(61-80+\text { yrs }) 21\end{array}$ & $\begin{array}{l}\text { MadarassaMuallima5 } \\
\text { Dar se Quran teachers } \\
\text { (muallima+other qualifications) } 6 \\
\text { Housewives } 31 \\
\text { Doctor } 12 \\
\text { Architect } 1 \\
\text { Schoolteacher } 9 \\
\text { (College) } 7\end{array}$ & $\begin{array}{l}\text { Muallima } 5 \\
\text { MA/M.Sc. } 17 \\
\text { M.Phil. } 4 \\
\text { MBBS } 4 \\
\text { MBBS MRCP/FCPS } 8 \\
\text { BA/B.Sc. } 32 \\
\text { Architect1 }\end{array}$ & $\begin{array}{l}\text { Ahle Sunnah } 19 \\
\text { Ahle Hadith } 23 \\
\text { AhleTashi } 16 \\
\text { Deobandi } 13\end{array}$ \\
\hline
\end{tabular}

Procedure. The selection of initial sample of participants was from personal and familial contacts and friendship circles. An introduction was secured before contacting each of the participants. Confidentiality was ensured and participants were assured that no information will be used to hold anything against their particular sect. Throughout the research, all further participants were indicated by prior participants as known for their knowledge of Islam, commitment to practice and generally a sound Muslim profile. One common venue to find out participants throughout the research remained the popular dars-e-Quran (lectures and discussions on Quran and Hadith arranged by neighbours; it is a popular practice in Lahore and other areas in Pakistan). Procuring participants from these lectures was very helpful as they had already gathered holding discussions on Islam. As basic understandings of Islam emerged during interviews, more participants were contacted to gather answers on each round of interviews.

Following the Glaserian dictum "all is data," the researcher consulted sources as newspaper articles on issues around Islam in Pakistan, personal interactional observations, popular cultural statements, and discussions on social media on Muslim religious extremism. This helped in constant comparisons of participants' talk with them as to achieve abstractions moving beyond participants' descriptions only (see Glaser, 2007).Tape recording is not encouraged in Glaserian method as a time consuming process and also because rather than full coding of all parts of a talk in a descriptive way, what is important is not actual words but abstraction of the relevant concepts emerging. Rather, field notes and memos were written alongside data collection. These focused on one's own reflections regarding the cognitive and psychological processes reflected in talk than recording all superfluous descriptions. The relevant parts of talk, views and information that collated to form themes are presented in coding charts.

\section{Analysis}

Coding was done in three stages namely open, selective and theoretical coding. In open coding, the raw data was fractured into discrete sets using constant comparisons by comparing one piece of talk with another, with other popular views, media sources, social media sharing of opinions, etc., and categories of similar phenomena were formed. Selective coding condensed further the concepts. These were the core categories developed through densification and explaining most variations, and relating to other categories at this stage in a meaningful way (Glaser, 2001), to be focused for concepts formulated at theoretical coding stage. To facilitate this, new questions were continuously reformulated to confirm and consolidate these categories. At theoretical coding stage, a final concept emerged which contained the previous categories and themes and where talking to more participants did not results in new information or evidence. The overall procedure 
followed comparing views with other information to develop categories, then matching further data with these categories, and categories with relevant categories to further densify towards theoretical concepts. This stage resulted in dense, and saturated final categories and their inter-relationships in a model as the final product. The format of coding charts follows Sbaraini, Carter, Evans and Blinkhorn (2011).Following are the theoretical concepts followed by the grounded theory model of cognitive and psychological processes involved in understandings and experience of faith by Muslims.

Theoretical concepts. To qualify as a basic social process, it was ensured that each core category is pervasive or reflects the patterns of responses, and that it has "two or more clear emergent stages" (Glaser, 1978, p. 97). The following core categories emerged as a result of rounds of data collection and interpretation. Though raw data to support each emerging pattern was collected at each stage, here it is summerized in first column of each table. The responses, which formed the counter-narrative to each core category, though very few, are presented with it for comparisons.

Totalitarianism is an ideology in which one form of thought at a state level holds total authority over the society and seeks to control all aspects of public and private life, all social institutions, academic disciplines including arts, literature, sciences, and culture and social customs, etc. The ideology does not tolerate any differing opinion and exercises dictatorial control over freedom, will and thoughts of all others it aims to be its subjects. An Islamist religious totalitarian thinking may, for example, have no regard for a national legal system if considered outside Islam.

Table 2

Totalitarianism: Coding Levels

\begin{tabular}{|c|c|c|c|}
\hline Raw data & Open/Initial Codes & Selective/Focused codes & Theoretical codes \\
\hline $\begin{array}{l}\text { All forms of knowledge as sciences, literature, fiction should } \\
\text { be shaped in accordance with our religion. } \\
\text { Secular thinkers should not be a part of our syllabi as we are } \\
\text { Muslims. } \\
\text { Education should not be liberal; it should stress propagating } \\
\text { religious values only. } \\
\text { I think schools imparting religious education are grooming } \\
\text { our children better than other schools that emphasize other } \\
\text { subjects. } \\
\text { A panel of religious scholars should be appointed to censor } \\
\text { every publication to make it in accordance with our religion. } \\
\text { Making of films, drama and theatrical performances should } \\
\text { be totally banned in an Islamic state. } \\
\text { Folk tales as Heer-Ranjha, Sassi-Punu, and Sohni-Mahinwal } \\
\text { should be banned as they preach love before marriage which } \\
\text { is un-Islamic. } \\
\text { Population control is against our religion. The state should } \\
\text { encourage and not discourage to produce more children to } \\
\text { increase the Ummah. Why all these population control plans? } \\
\text { Child marriage is a western myth. it should be mandatory for } \\
\text { a nine years old Muslim child to get married. } \\
\text { If Taliban talks with Government was about getting married } \\
\text { someone as early as possible, we should see the crux matter. } \\
\text { They want obscenity to be put to an end. The sooner you get }\end{array}$ & $\begin{array}{l}\text { Issuing normative } \\
\text { religious orders } \\
\text { without } \\
\text { consideration of } \\
\text { social and historical } \\
\text { context. }\end{array}$ & $\begin{array}{l}\text { Restriction, censorship } \\
\text { and control of all walks } \\
\text { of life to achieve } \\
\text { subjugation to one total } \\
\text { principle. }\end{array}$ & $\begin{array}{l}\text { Totalitarian state } \\
\text { seen as the } \\
\text { ultimate goal of } \\
\text { Islam. }\end{array}$ \\
\hline
\end{tabular}




\begin{tabular}{|l|l|l|}
\hline married, the better. & \\
\hline $\begin{array}{l}\text { I think nationalism is clearly a secular and anti-Islamic term. } \\
\text { National slogans as national anthem, songs, flag and } \\
\text { national holidays are un- Islamic innovations and should be } \\
\text { banned in an Islamic country. }\end{array}$ & \\
$\begin{array}{l}\text { Jihad is needed to replace the stupid democracy with a } \\
\text { khalifah who would crush secularlism and be a living } \\
\text { example of Islam. }\end{array}$ & $\begin{array}{l}\text { Opposing } \\
\text { nation-state and } \\
\text { nationalism as } \\
\text { anti-islamic. }\end{array}$ & \\
$\begin{array}{l}\text { What laws are to be respected? Those that do not have an } \\
\text { Islamic basis? Well, I live here and do not break laws, but if } \\
\text { time comes then I don't think an allegiance with anther } \\
\text { Islamic country is wrong. Islam does not have boundaries. } \\
\text { They are just imposed by country. }\end{array}$ & \\
\hline $\begin{array}{l}\text { Islam should be enacted through force by the state because it } \\
\text { is the only true path. }\end{array}$ & $\begin{array}{l}\text { Enforcing one's own } \\
\text { version of religion } \\
\text { through state. }\end{array}$ \\
$\begin{array}{l}\text { A shariah based system is needed here where minorities as } \\
\text { XYZ will pay jizyah ( tax) for living in a Muslim government. } \\
\text { Strict legal reforms should be enforced to curb people } \\
\text { expressing secular views. }\end{array}$ & $\begin{array}{l}\text { Curbing } \\
\text { democratic/liberal } \\
\text { system with rigid } \\
\text { religious ideals. }\end{array}$ & \\
$\begin{array}{l}\text { Islam would never gain its due respect until it is enforced by } \\
\text { the state to control thought and action of all institutions. }\end{array}$ & \\
\hline
\end{tabular}

Closed mindedness or Myopic thinking is conceptualized as a dogmatic approach, avoidance of free inquiry into phenomena and critical thought, and a neglect of counter-belief information; it also involves a resistance to change and reflects rigidness. It reflects a denial of reaching reality through personal quest and seeking and validating only that knowledge /information that confirms one's beliefs.

Table 3

Closed Mindedness: Coding Levels

\begin{tabular}{|c|c|c|c|}
\hline Raw Data. & Open/Initial Codes & Selective/Focused codes & Theoretical codes \\
\hline $\begin{array}{l}\text { Islam is a complete code of conduct, thinking about other } \\
\text { philosophies is not useful. } \\
\text { Thousands of recipies of how to be this or that or how to do } \\
\text { this or that. People go to psychologists when they do not have } \\
\text { Islam. If deen is there, then of course no psychological } \\
\text { problems. what's the use of any guidance from counsellors } \\
\text { when Islam is there to guide? } \\
\text { I am proud to belong to a religion that gives me a complete } \\
\text { code of life, then what is the use of so much thinking and } \\
\text { thinking; this philosophy and that philosophy? why? Just to } \\
\text { bring in fitnah (unrest/evil)? To invite trouble when it is not } \\
\text { there? }\end{array}$ & $\begin{array}{l}\text { Complete religion } \\
\text { understood as } \\
\text { closed religion. }\end{array}$ & \multirow[t]{3}{*}{$\begin{array}{l}\text { Islam seen as an agent } \\
\text { curbing critical thinking } \\
\text { and inquiry. }\end{array}$} & \multirow{4}{*}{$\begin{array}{l}\text { Closed/Myopic } \\
\text { thinking. }\end{array}$} \\
\hline $\begin{array}{l}\text { It is almost as if we have the latest model for something, why } \\
\text { go to previous and old models that are out of date. } \\
\text { Islam is the best and the newest. }\end{array}$ & $\begin{array}{l}\text { Islam as modern, } \\
\text { the rest of religions } \\
\text { outdated. }\end{array}$ & & \\
\hline $\begin{array}{l}\text { We were not created for discovering everything anew; truth is } \\
\text { there in Islam. } \\
\text { Islam means submission not asking questions. } \\
\text { When you are guided by Satan, then of course ideas as liberal } \\
\text { thinking pop up. When you submit, then you submit than } \\
\text { thinking about whys. }\end{array}$ & $\begin{array}{l}\text { Submission to the } \\
\text { will of God and } \\
\text { inquiry as opposites }\end{array}$ & & \\
\hline When everything is there, just act on it and you will be & Danger of losing & Strategic rejection of & \\
\hline
\end{tabular}




\begin{tabular}{|c|c|c|}
\hline $\begin{array}{l}\text { peaceful. Those who want to become philosophers are half } \\
\text { mad. } \\
\text { Free inquiry would do nothing but to lead away from Islam. } \\
\text { Thinking about everything should be guided by Islam, } \\
\text { otherwise one would leave the right path. } \\
\text { People easily violate shariah when they start thinking freely. } \\
\text { If you start anew for truth, then of course you are going to } \\
\text { change many religions. }\end{array}$ & $\begin{array}{l}\text { Islam with free } \\
\text { thinking; }\end{array}$ & \multirow{3}{*}{$\begin{array}{l}\text { counter-belief } \\
\text { information } \\
\text { through evoking guilt, } \\
\text { giving warnings of } \\
\text { leaving the right path, } \\
\text { and degrading creative } \\
\text { capabilities as madness. } \\
\end{array}$} \\
\hline $\begin{array}{l}\text { Thinking about things that go against Islamic beliefs is a sin, } \\
\text { there is no question about it. } \\
\text { It is a mischief to pop up things and events that reject Islamic } \\
\text { way. }\end{array}$ & Inducing guilt & \\
\hline $\begin{array}{l}\text { Many so called arts are true fitnah. They are always } \\
\text { conjuring new idols called pieces of art and calling } \\
\text { themselves Muslim artist. }\end{array}$ & $\begin{array}{l}\text { Degrading attitude } \\
\text { towards creativity } \\
\text { and aesthetics. }\end{array}$ & \\
\hline
\end{tabular}

Hyper- Exotericism involves an obsession with preserving the outward and normative form of religion. It involves approaching religion through visible signs of piety as outward appearance in dress, beard, veil, etc. As opposed to esoteric dimension concerned with self purification, it is concerned with strict adherence to rules and rituals and their minor details for achieving completion and perfection in religion. Emphasizes form over spirit/meaning and is literalistic; for instance, taking sculpture as idolatry. It dismisses an insight into the interiority of others and evaluates them by appearances only. It is thus unable to demythologize the symbol or understand its meaning behind forms. Hyper-exotericism also refuses to see similarity of spirit in various symbols across religious traditions. It shows intolerance for inward, subjective, individualistic and mystical religion and gives no emphasis to inward experience of the mystical reality. It thus involves an intolerance of spiritual practices as including the chanting of God's attributes, sacred music, ritual dancing or the veneration of Islamic saints. Tilted towards objectivity, a can show a highly scientific and logical view of religion, e.g., proving religion through science, and a corresponding intolerance for beyond-logical, subjective, emotional and mystical side of religion. Hyper exotericism also has an outward locus of authority and discourages one's own understanding to be used in matters of religion. A totally outward locus of authority results in little self search into religion or taking it as a sin.

Table 4

Hyper-Exotericism: Coding Levels

\begin{tabular}{|l|l|l|l|}
\hline Raw data & Open/Initial Codes & Selective/Focused codes & Theoretical codes \\
\hline $\begin{array}{l}\text { There are clear cut fat was about everything in our religion; } \\
\text { follow them otherwise throughout your life you won't be able } \\
\text { to find out right and wrong. }\end{array}$ & $\begin{array}{l}\text { Conviction that only } \\
\text { It is far practical to consult a religious scholar in deciding } \\
\text { about good and evil than using our own ideas. } \\
\begin{array}{l}\text { Deciding about good and evil cannot be done without proper } \\
\text { training in Islamic law. } \\
\text { Reedigious scholars are there to tell us what is Islam, not you } \\
\text { decide about right } \\
\text { and wrong } \\
\text { and me. }\end{array}\end{array}$ & $\begin{array}{l}\text { Outward locus } \\
\text { of authority }\end{array}$ & Hyper-exotericism \\
$\begin{array}{l}\text { Inner life, inner feelings, own self, I wonder if these terms are } \\
\text { If conscience is there, it is the gift of Islam to a Muslim. }\end{array}$ & $\begin{array}{l}\text { Refusal to accept } \\
\text { that a } \\
\text { genuine conscience } \\
\text { exists }\end{array}$ & \\
\hline
\end{tabular}




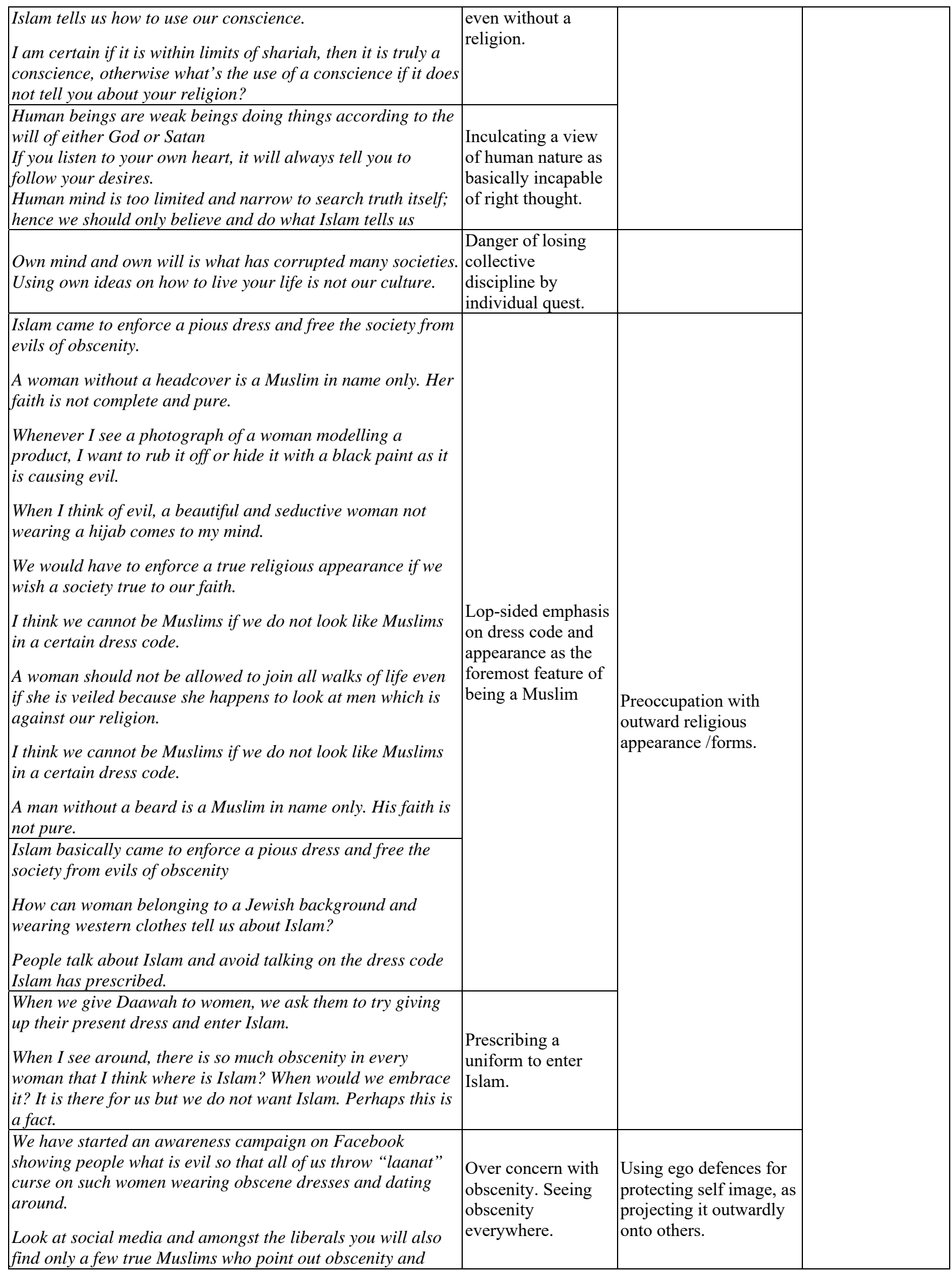




\begin{tabular}{|l|l|l|}
\hline condemn it. & \\
\hline $\begin{array}{l}\text { She is not innocent; people need to be told what she is. She is } \\
\text { a shameless woman having affairs with politicians. She } \\
\text { should know the after math so that others do not follow her. }\end{array}$ & \\
$\begin{array}{l}\text { If our daughters are impressed by these newscasters, } \\
\text { anchorperson, and all the dirty women in media showing } \\
\text { their beauty, then its better to tell them how ugly they are. }\end{array}$ & $\begin{array}{l}\text { Projecting perceived } \\
\text { evil } \\
\text { ineasy/vulnerable } \\
\text { targets. }\end{array}$ & \\
$\begin{array}{l}\text { One of them was doing an obscene dance with a policeman, I } \\
\text { was watching and thinking, "Are we Muslims?" }\end{array}$ & & \\
\hline
\end{tabular}

Ambiguity intolerance is avoidance of religious controversies; feeling that faith will be insecure in case of any ambiguity; denying controversy in religion or religious history; insistence that everything is clear-cut and usually in the form of prescriptions; a refusal to gain insight into complexity of things.

Table 5

Ambiguity Intolerance: Coding Levels

\begin{tabular}{|c|c|c|c|}
\hline Raw data & Open/Initial Codes & Selective/Focused codes & Theoretical codes \\
\hline $\begin{array}{l}\text { There are clear injunctions on how to eat, how to drink, how } \\
\text { to socialize, how to live your life in short. So if Islam says eat } \\
\text { with right hand, you would create difficulty by saying no eat } \\
\text { with left hand. } \\
\text { Thinking about what could be another better way is trying to } \\
\text { make innovations when ways are clear to you. }\end{array}$ & $\begin{array}{l}\text { Emphasis on praxis } \\
\text { than philosophy }\end{array}$ & \multirow{7}{*}{$\begin{array}{l}\text { Using Divine } \\
\text { justification for } \\
\text { ambiguity avoidance }\end{array}$} & \multirow{10}{*}{$\begin{array}{l}\text { Ambiguity, } \\
\text { controversy and } \\
\text { doubt avoidance }\end{array}$} \\
\hline $\begin{array}{l}\text { I ask you one question; If someone is disrespectful of XYZ } \\
\text { person in Islamic history, what clarity do you further want to } \\
\text { regard him as a non Muslim. This is how simple things are } \\
\text { made complicated. Would God take him as a Muslim? }\end{array}$ & & & \\
\hline $\begin{array}{l}\text { We were created to live our lives in accordance with Islam } \\
\text { and that is the reality. Mystery is there but what is the use of } \\
\text { searching what God has kept secret. } \\
\text { Allah says He has made Islam simple to understand. } \\
\text { Still if people want doubt, it is their own created fitnah } \\
\text { (unrest/evil). }\end{array}$ & $\begin{array}{l}\text { Over simplified } \\
\text { thinking }\end{array}$ & & \\
\hline $\begin{array}{l}\text { There is no controversy in Islam; those who have left clear } \\
\text { injunctions over everything want to be in doubt. } \\
\text { Those who hanker after doubtful things will be punished for } \\
\text { leaving the clear orders. }\end{array}$ & & & \\
\hline $\begin{array}{l}\text { Those who raise doubtful questions about Islam are not true } \\
\text { Muslims. }\end{array}$ & $\begin{array}{l}\text { Associating guilt } \\
\text { with controversy. }\end{array}$ & & \\
\hline Doubt is sin. It comes from the satan. & & & \\
\hline $\begin{array}{l}\text { Thinking is not banned, but there are bounds for it. Otherwise } \\
\text { one could go on for every sort of haram (forbidden) thinking. }\end{array}$ & & & \\
\hline $\begin{array}{l}\text { Early Muslims great achievements in everything. This is } \\
\text { because they acted on Islamic injunctions and were pious. }\end{array}$ & & \multirow{3}{*}{$\begin{array}{l}\text { Strategies to avoid } \\
\text { controversy: over } \\
\text { simplification, } \\
\text { avoidance of } \\
\text { controversial } \\
\text { information. }\end{array}$} & \\
\hline $\begin{array}{l}\text { The rules are there and if we follow what pre decessors } \\
\text { followed and remain true to fundamentalism of Islamthen } \\
\text { success is there. Bu today all culture is very liberal and } \\
\text { confusing things already laid down. }\end{array}$ & $\begin{array}{l}\text { Gross } \\
\text { generalizations }\end{array}$ & & \\
\hline $\begin{array}{l}\text { If some people have written wrong history causing } \\
\text { controversies about important events, then thumb rule is to } \\
\text { avoid those writings. } \\
\text { Whatever happened in } \mathrm{XYZ} \text { war is very clear. They have }\end{array}$ & $\begin{array}{l}\text { Rejecting } \\
\text { controversial } \\
\text { historical } \\
\text { information. }\end{array}$ & & \\
\hline
\end{tabular}




\begin{tabular}{|l|l|l|}
\hline $\begin{array}{l}\text { exaggerated to induce controversies. Rather than allowing } \\
\text { them to continue with the practice, it would have been better } \\
\text { that they were regarded as non Muslims. }\end{array}$ & & \\
\hline $\begin{array}{l}\text { I dislike the character of Ranjha as he tended to see God in a } \\
\text { woman he loved } \\
\begin{array}{l}\text { All prophets and saints are dead and hence calling them as if } \\
\text { they are present is a great sin. }\end{array}\end{array}$ & $\begin{array}{l}\text { Normative thinking } \\
\text { opposed to contexts } \\
\text { of understanding. }\end{array}$ & Literalistic tendencies \\
$\begin{array}{l}\text { Seeing God? In murshad (spiritual guide in Islamic mystical } \\
\text { tradition)? What else is shirk? }\end{array}$ & $\begin{array}{l}\text { Refusal of } \\
\text { abstraction }\end{array}$ & \\
\hline $\begin{array}{l}\text { Any person claiming that he is one with God is shirk. } \\
\text { should be banned. }\end{array}$ & \\
\hline
\end{tabular}

Authoritarianism reflects desire for overpowering and controlling others; oppression of weaker targets, subjugating them to an unquestioning obedience and scapegoating them; hostility towards those not fulfilling these norms; women are most common targets and misogyny is justified through discourses as need of a ordered pattern of household with one head subjugating all others to his desires; husband-wife relation constructed on non-mutual and abusive rather than humanistic frameworks. Authoritarianism shows an intolerance for egalitarianism, all forms of human rights as women's children's and minorities' rights; perceiving human rights as a western implanted agenda against Muslims; seeing human rights as something not to be discussed in its own right; seeing violations of human rights as divine orders and necessary for keeping society intact.

Table 6

Authoritarianism: Coding Levels

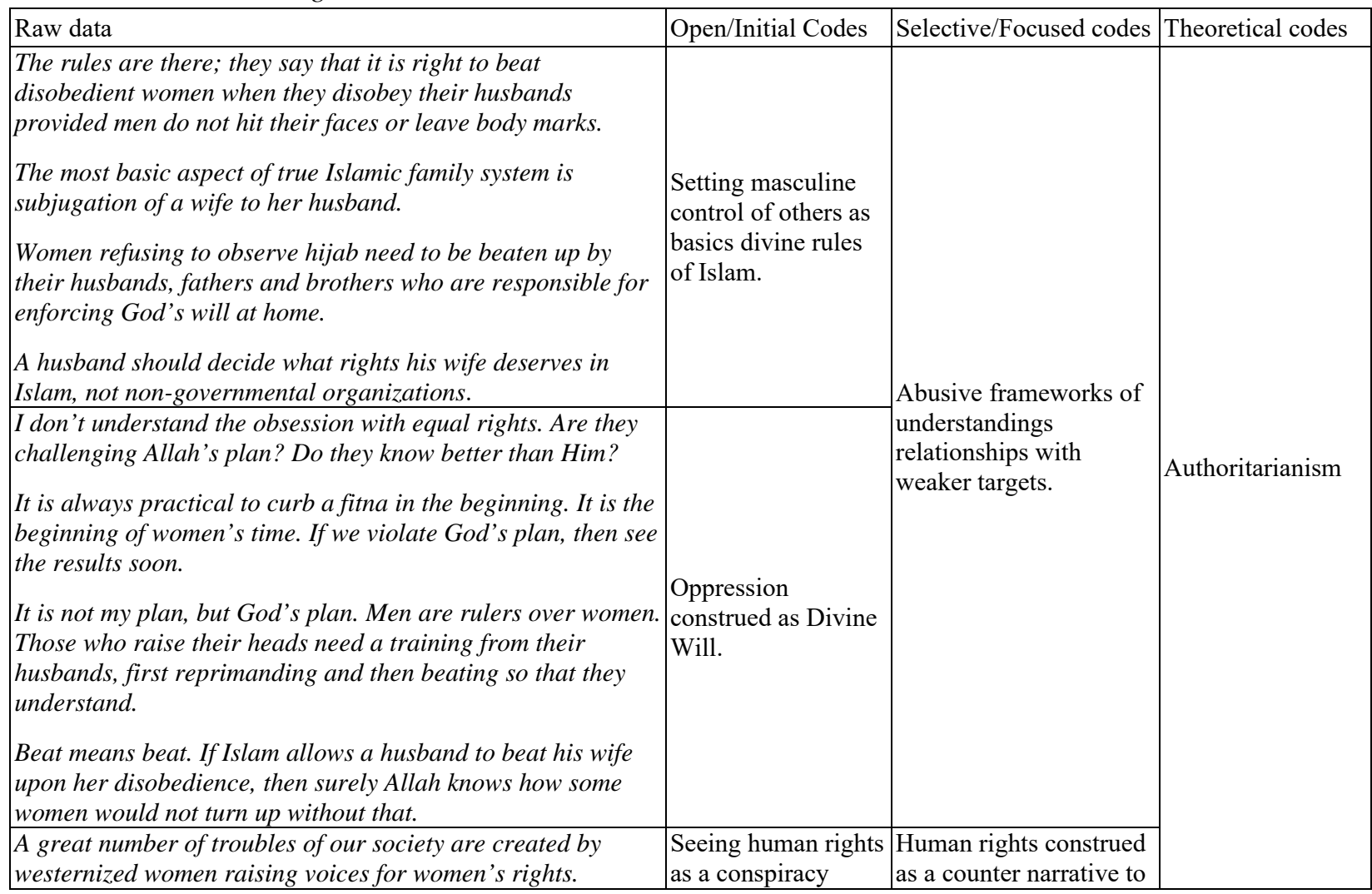




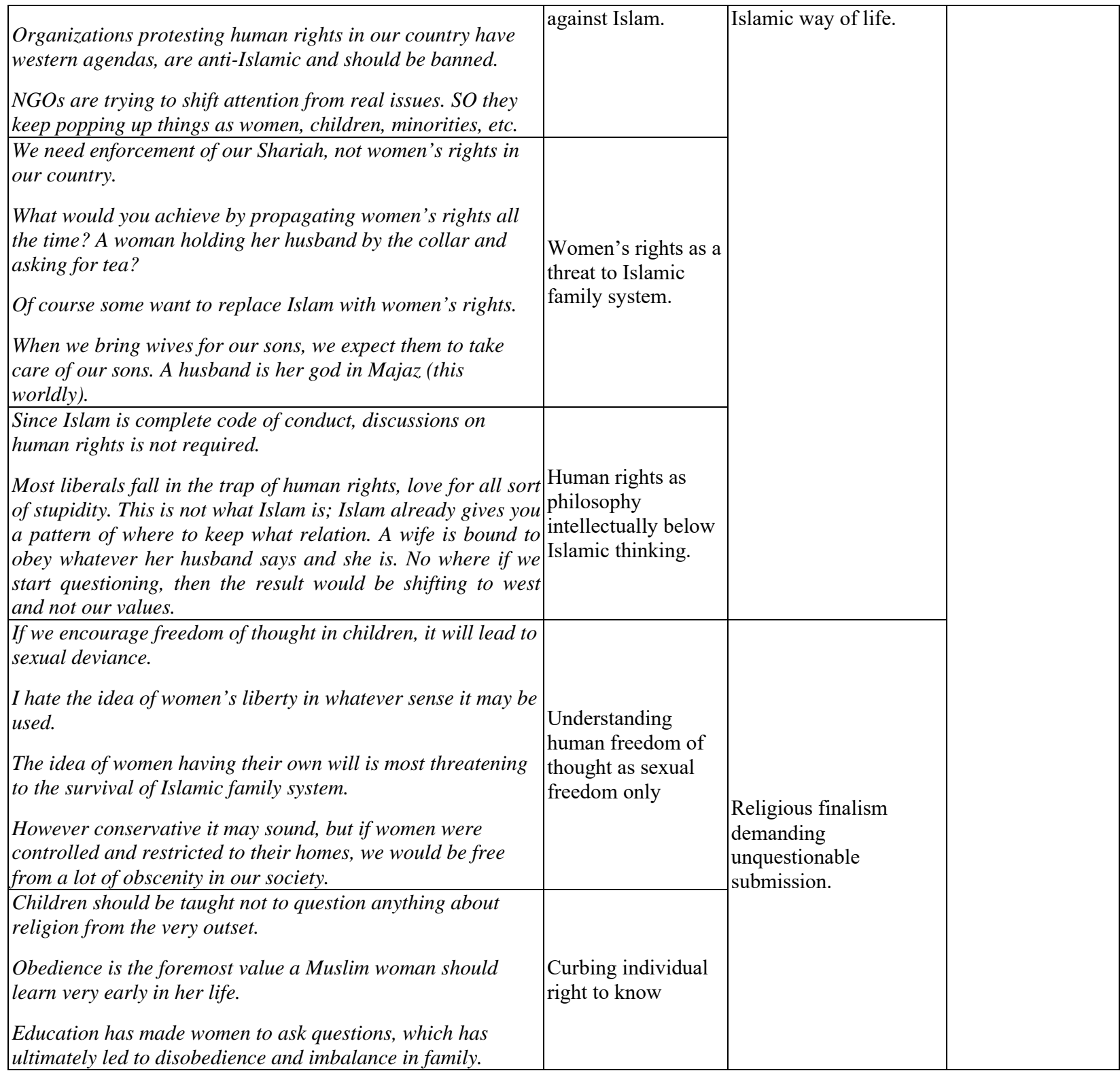

Binary/ dichotomous thinking is largely composed of two mutually exclusive and opposite options only; black or white, good or evil, Islamic or un-Islamic, heaven and hell, this world and next world, us and them, Muslims and kafirs, insiders and outsiders; veiled women and unveiled women; shia and sunni. One result is drawing more differences than similarities between Islam and other religions when they are understood as non -Islam.

Table 7

Dichotomous Thinking: Coding Levels

\begin{tabular}{|l|l|l|l|}
\hline Raw data & Open/Initial Codes & Selective/Focused codes & Theoretical codes \\
\hline $\begin{array}{l}\text { All forms of knowledge except Quran and Hadith are worldly } \\
\text { and have nothing to do our life hereafter. }\end{array}$ & $\begin{array}{l}\text { Bifurcation of } \\
\text { wordly and other } \\
\text { wordly knowledge. }\end{array}$ & $\begin{array}{l}\text { Understanding } \\
\text { everything as either } \\
\text { Islamic or non-Islamic } \\
\text { is that of religion. }\end{array}$ & $\begin{array}{l}\text { Dichotomous } \\
\text { thinking }\end{array}$ \\
\hline
\end{tabular}




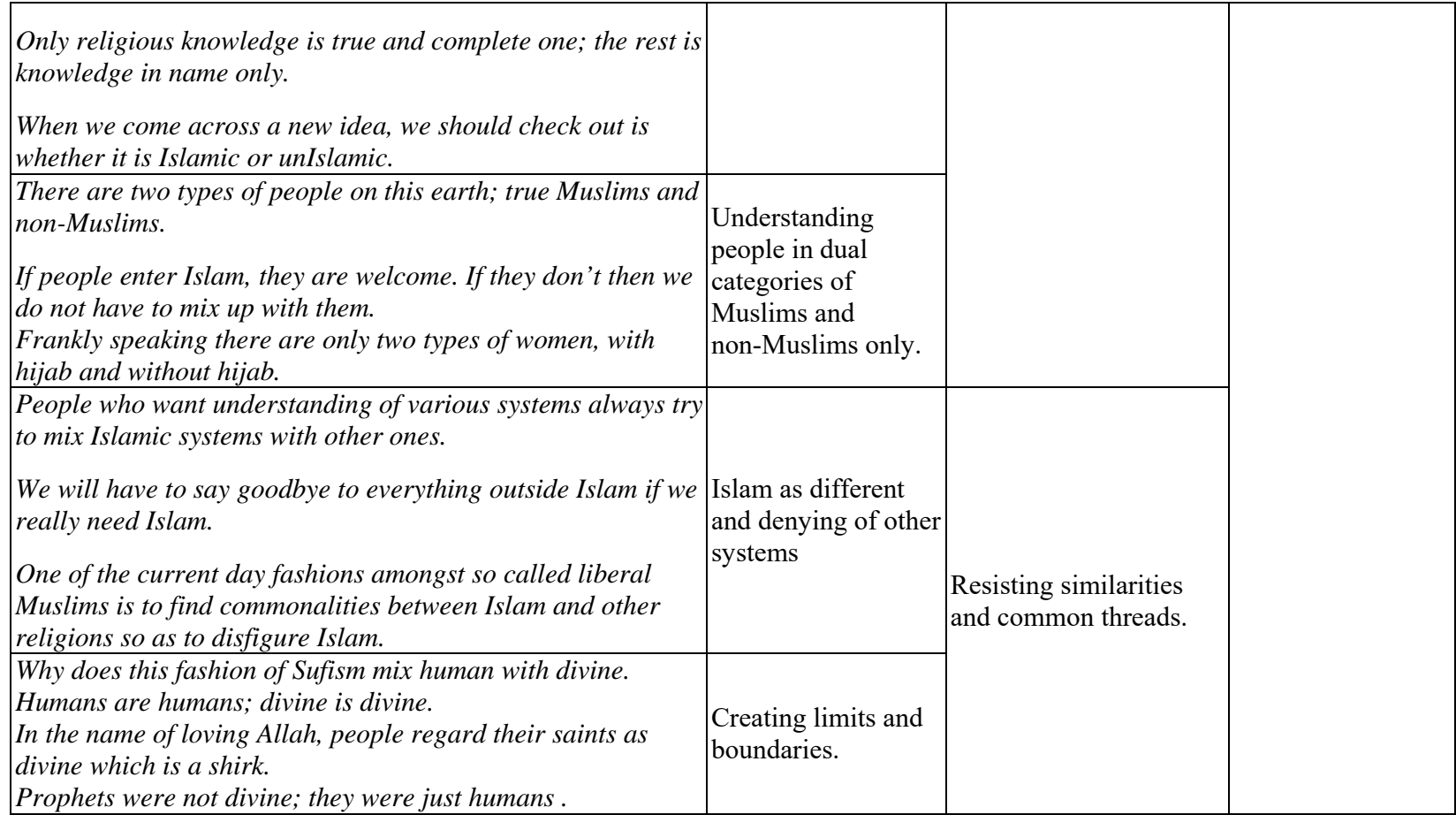

Punitive approach is a wish to punish any dissent from one's own version of religion given common labels as deviants, seculars, non-Muslims, critics of religion, liberals, atheists; a desire to teach others a lesson, thinking of punishment as necessary for grooming a human being; punishing anything considered outside religion; justifying bomb blasts as a suitable punishment for unIslamic life styles; thinking with God's mind and suggesting appropriate punishment for people; feeling little sympathy for targets; wishing for authorities working as prosecutors of women/children/minorities so as to keep social order; thinking of punishment as a necessary ingredient of reviving Islam in social life.

Table 8

Punitive Approach: Coding Levels

\begin{tabular}{|c|c|c|c|}
\hline Raw data & Open/Initial Codes & Selective/Focused codes & Theoretical codes \\
\hline $\begin{array}{l}\text { Bomb blasts are all punishment for obscenity in our society. } \\
\text { Bomb blasts are a natural reaction to an un-Islamic } \\
\text { government. May be you have offended those who want } \\
\text { Shariah so much that they also want to tell you that they exist. }\end{array}$ & $\begin{array}{l}\text { Perceiving } \\
\text { punishment as } \\
\text { automatic and } \\
\text { naturally justified. }\end{array}$ & \multirow{5}{*}{$\begin{array}{l}\text { Punishment as a way get } \\
\text { one's world view } \\
\text { confirmed. }\end{array}$} & \multirow{5}{*}{ Punitive attitude } \\
\hline $\begin{array}{l}\text { If it is said, a nod to the wise and a rod to the otherwise, then } \\
\text { is rightly said for our society; so much obscenity? So much } \\
\text { non-Muslim attitudes? Things are getting so serious that we } \\
\text { need to fight the root cause; even animals respond to } \\
\text { punishment; why not humans? }\end{array}$ & $\begin{array}{l}\text { Suggesting } \\
\text { punishment as the } \\
\text { only way of dealing } \\
\text { with perceived evil }\end{array}$ & & \\
\hline $\begin{array}{l}\text { If it were in my hands, I would have severely punished the } \\
\text { Christians for their wrong beliefs. }\end{array}$ & \multirow{3}{*}{$\begin{array}{l}\text { Suggesting } \\
\text { punishment for } \\
\text { wrong beliefs }\end{array}$} & & \\
\hline $\begin{array}{l}\text { If it were in my hands, I would have severely punished the } \\
\text { Jews for their wrong beliefs. } \\
\text { Some sects in Islam are worse than kafirs and non-believers } \\
\text { and should enter the fire of hell. }\end{array}$ & & & \\
\hline $\begin{array}{l}\text { Some scholars teaching a more liberal brand of Islam should } \\
\text { be forced into exile. }\end{array}$ & & & \\
\hline
\end{tabular}




\begin{tabular}{|c|c|c|}
\hline $\begin{array}{l}\text { People criticizing Islam should be punished to death in our } \\
\text { country. }\end{array}$ & & \\
\hline $\begin{array}{l}\text { The scholars you are mentioning were killed for their own } \\
\text { mistakes; who asked them to say Jihad should not be done? } \\
\text { Who asked them to be advocates of non-Muslims? }\end{array}$ & $\begin{array}{l}\text { Blaming the victim } \\
\text { as deserving of } \\
\text { punishment. }\end{array}$ & \\
\hline $\begin{array}{l}\text { If media would show women in a sexually attractive way, then } \\
\text { of course results would be more and more rapes. } \\
\text { Western ideas have made people think women can do } \\
\text { whatever they like and then also complain that they were } \\
\text { teased, harassed and raped. }\end{array}$ & $\begin{array}{l}\text { Justifying } \\
\text { offenses/assaults via } \\
\text { third party } \\
\text { responsibility }\end{array}$ & $\begin{array}{l}\text { Portraying the offender } \\
\text { as passive in an offense. }\end{array}$ \\
\hline
\end{tabular}

Violent tendencies show up as feeling negative emotions during a discussion on religion; justifying violence and extremism on grounds that others are also doing the same; considering arms and ammunition an important part of spreading Islam; denying that there is anything called as religious extremism; feeling a strong urge to carry ammunition and go for a fight with non-Muslims; thinking that using ammunition against all non-Muslims is more important than anything else.

Table 9

Violent Tendencies: Coding Levels

\begin{tabular}{|c|c|c|c|}
\hline Raw data & Open/Initial Codes & Selective/Focused codes & Theoretical codes \\
\hline $\begin{array}{l}\text { Extremist is a label wrongly used to describe true Muslims in } \\
\text { Pakistan. } \\
\text { No Muslim is involved in terrorist attacks. } \\
\text { It has become a fashion of the west to find out extremists } \\
\text { amongst Muslims.How can a Muslim be a terrorist? }\end{array}$ & $\begin{array}{l}\text { Resisting that } \\
\text { religious extremism } \\
\text { exists amongst } \\
\text { Muslims. }\end{array}$ & \multirow{3}{*}{ Instrumental aggression } & \multirow{6}{*}{$\begin{array}{l}\text { Aggressive } \\
\text { tendencies }\end{array}$} \\
\hline $\begin{array}{l}\text { Jihadi groups of our country are justified to some extent if } \\
\text { they are working for the enforcement of Islam. } \\
\text { The proper course of action is to call people towards the true } \\
\text { version of Islam and then if they deny, wage a jihad against } \\
\text { them. }\end{array}$ & $\begin{array}{l}\text { Perceiving violence } \\
\text { as a necessary way } \\
\text { to curb anti-Islam } \\
\text { sentiment. }\end{array}$ & & \\
\hline $\begin{array}{l}\text { The religious groups are called extremists just because they } \\
\text { keep ammunition. There is nothing wrong with it if } \\
\text { ammunition has a licence. If they are always at stake so much } \\
\text { so that whenever you come and ruin them, then they can also } \\
\text { take arms against the so called governments. } \\
\text { Governments has no right to take action against sacred } \\
\text { places. } \\
\text { Some western nations are also doing the same to Muslims. }\end{array}$ & $\begin{array}{l}\text { Framing violence as } \\
\text { a strategy of } \\
\text { defence. }\end{array}$ & & \\
\hline $\begin{array}{l}\text { A suicide bomber exploding himself at a place full of } \\
\text { obscenity and malpractice may go to heaven as his/her } \\
\text { intention was to give his life for Islam. } \\
\text { A suicide bomber killing Israelites people in the episode will } \\
\text { definitely go to heaven. } \\
\text { If there is sword beneath the Kalima, I do not hate the sword } \\
\text { then. What's wrong with it? }\end{array}$ & $\begin{array}{l}\text { Idealizing the sword } \\
\text { and jihad; } \\
\text { Emotional } \\
\text { attachment with } \\
\text { violence. }\end{array}$ & \multirow[t]{3}{*}{ Hostile aggression } & \\
\hline $\begin{array}{l}\text { Sometimes, I feel like giving up my studies or job and join a } \\
\text { Jihadi group to serve Islam. }\end{array}$ & & & \\
\hline $\begin{array}{l}\text { I get emotional when someone talks about true Islam in a bad } \\
\text { way. There are so many instances that now I already can tell } \\
\text { you what it is going to be like before he talks and I know I am } \\
\text { enraged a bit much before he talks. }\end{array}$ & Venting out hostility & & \\
\hline
\end{tabular}




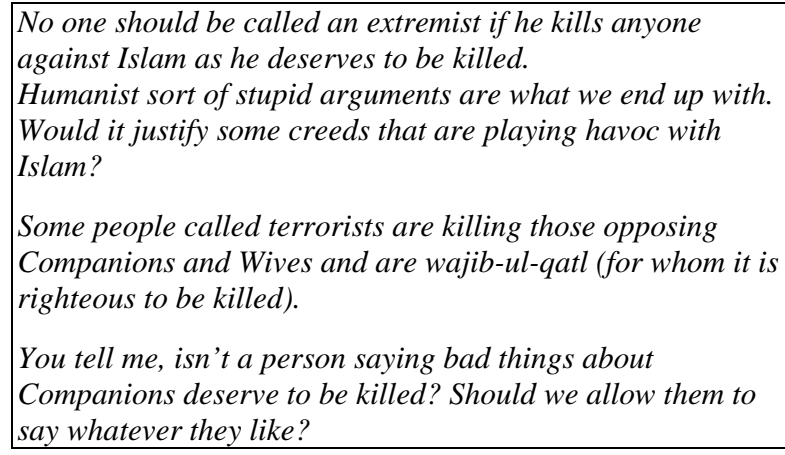

Labelling is an essentialist social perception in which one thinks about various social categories as gender, ethnicity, religious identity as carrying certain traits inherently; and then offering explanation of related phenomena according to these categories. The tendency was to understand certain categories in ways complying with one's religious injunctions.

Table 10

\section{Labelling: Coding Levels}

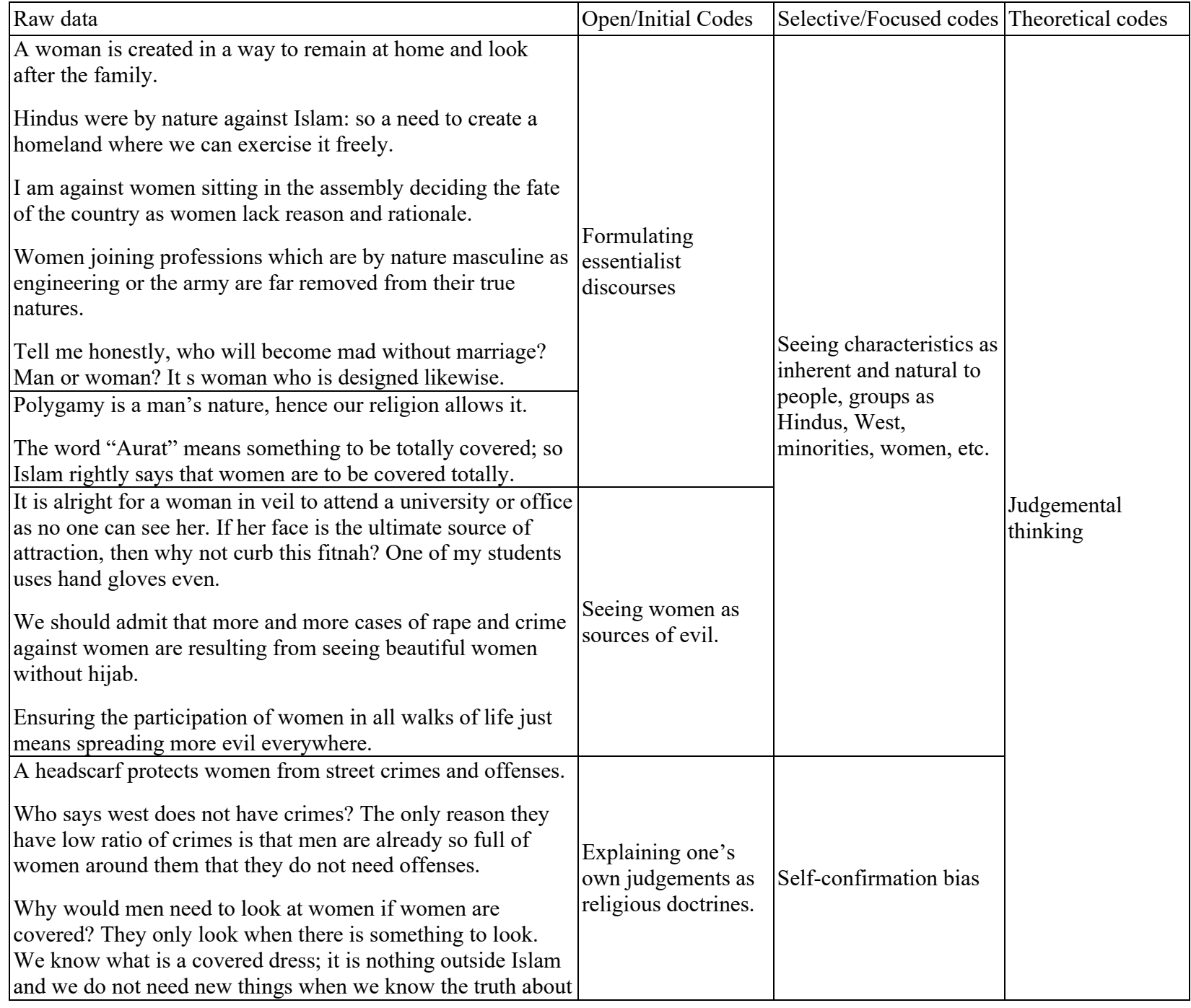




\begin{tabular}{|l|l|}
\hline men and their nature. & \\
Why would men need to tease women and look at them if \\
they have wives? I think the principle is in accordance with \\
our fitrah. I don't think
\end{tabular}

Diversity intolerance is intolerance for religious and cultural diversity resulting from the perception that there is only one true and authentic version of Islam which should eradicate the wrong ones. It is an attitude of extreme self-righteousness as a "true Muslim" excluding others as being not on right path; feeling it a duty to convert others to one's own sect; perceiving that people belonging to other sects are not pure in their faith; challenging the authenticity of other religious affiliations; refusing to gain knowledge of other's religious perspective considering it a sin and an amalgamation in faith.

\section{Table 11}

\section{Diversity Intolerance: Coding Levels}

\begin{tabular}{|c|c|c|c|}
\hline Raw data & Open/Initial Codes & Selective/Focused codes & Theoretical codes \\
\hline $\begin{array}{l}\text { Muslims all over the world cannot succeed in this world and } \\
\text { the hereafter until and unless they all follow one authentic } \\
\text { version of Islam which is there in majority. } \\
\text { Islam is only one and does not have different versions } \\
\text { If we have one God, one Prophet and one Book than it is } \\
\text { obvious that we have only one way of reaching God. } \\
\text { Since Islam is a complete religion, there was never a need for } \\
\text { Sufism. } \\
\text { Sufism, peeri-mureedi (practices around spiritual masters } \\
\text { and their disciples) is a fashion for people who do not want } \\
\text { true Islam. }\end{array}$ & $\begin{array}{l}\text { Idealizing one true } \\
\text { and pure version of } \\
\text { Islam. }\end{array}$ & & \\
\hline $\begin{array}{l}\text { Why do we need to develop what you call a sympathetic } \\
\text { understanding of other sects and religions and why not Islam } \\
\text { and the true Islam? Isn't life too short for wandering away } \\
\text { hither and thither? Then why not stick to your values. } \\
\text { It is yet again another style of the liberal world to interact } \\
\text { with kuffar (disbelievers) and learn about their perspective. } \\
\text { I do not believe in Hindu Muslim Sikh Bhai bhai (brothers) as } \\
\text { kafirs (disbelievers) can never be our friends, why go one } \\
\text { step further and make them brothers. } \\
\text { If all religions are true, the my dear, what was the need for } \\
\text { Islam? } \\
\text { Truth is not a wind blowing everywhere. It is there in Islam } \\
\text { and only Islam. } \\
\text { If you give children and youth a sympathetic knowledge of } \\
\text { different religious and cultural traditions right from the } \\
\text { beginning, then they would be believers in all religions and } \\
\text { not Islam. } \\
\text { Since Islam evolved during history, many wrong sects }\end{array}$ & $\begin{array}{l}\text { Refusing other } \\
\text { religions/sects as } \\
\text { false. }\end{array}$ & Illusion of uniformity & $\begin{array}{l}\text { Diversity } \\
\text { intolerance }\end{array}$ \\
\hline
\end{tabular}




\begin{tabular}{|c|c|c|c|}
\hline $\begin{array}{l}\text { evolved. They have created their own versions, rituals, } \\
\text { practices, and not on the true path. }\end{array}$ & & & \\
\hline $\begin{array}{l}\text { Islam abrogated Indian culture and established a Muslim } \\
\text { caliphate in India through Muhammad bin Qasim. He taught } \\
\text { people how to live } \\
\text { their lives according to Islam. } \\
\text { Now when one is a Muslim then what's the purpose of being a } \\
\text { Jaat or Pathan; Islam came to erase these orders and their } \\
\text { elaborate rituals and difficult life styles. Companions set up a } \\
\text { mode of life purely Islamic and nothing else. } \\
\text { As Indians embraced Islam, they corrected themselves in } \\
\text { their dress, in eating habits, in everyday life encounters, in } \\
\text { false rituals which they had to give up. } \\
\text { Islam banned false worship in Iran. }\end{array}$ & $\begin{array}{l}\text { Understanding } \\
\text { Islam as a force that } \\
\text { abrogated existing } \\
\text { cultures it came in } \\
\text { contact with. }\end{array}$ & \multirow{4}{*}{$\begin{array}{l}\text { Perceiving culture as an } \\
\text { entity counter to Islam }\end{array}$} & \\
\hline $\begin{array}{l}\text { Islam came to put an end to jahilliyah (times of ignorance-a } \\
\text { word used to mark the pre-Islamic times; its root is juhl or } \\
\text { ignorance). There was no mehndibaarat (wedding festivals) } \\
\text { etc in early Islamic weddings. We got it from Hindus. } \\
\text { Before Islam, people were jahils (ignorant of truth, though } \\
\text { jahil may be literate), Islam abrogated all their practices and } \\
\text { replaced them with a new way of life. }\end{array}$ & $\begin{array}{l}\text { Islam versus } \\
\text { Jahilliyah } \\
\text { constructions } \\
\text { construing all others } \\
\text { beyond Islam as } \\
\text { Jhahilliyans. }\end{array}$ & & \\
\hline $\begin{array}{l}\text { I do not agree with the tern human cultures. There is only one } \\
\text { true human culture and that is Islam. } \\
\text { What is culture? I think this question has a very short answer. } \\
\text { It is set of bidahs (innovations) we love very much in order to } \\
\text { change Islam. } \\
\text { When everything is there in Islam, then what is the need for } \\
\text { clinging to words like culture, ritual, life style? }\end{array}$ & $\begin{array}{l}\text { Negating culture in } \\
\text { its own right outside } \\
\text { Islam. }\end{array}$ & & \\
\hline $\begin{array}{l}\text { Today, women are wearing western pants, studying libido, } \\
\text { libido, libido and libido. I know what are you studying in } \\
\text { Psychology, a Jew scoundrel. Where would Islamic culture } \\
\text { come from if you are studying western mode of thought? } \\
\text { One of the greatest threat to Islam today is the cultural } \\
\text { customs like those observed in celebrations of marriage and } \\
\text { other social celebrations. } \\
\text { Many of our marriage rituals are from Hindus. Why don't we } \\
\text { think that we are Muslims and not Hindus? } \\
\text { What we call culture is nothing but our Hindu adaptation of a } \\
\text { life style. Nothing else. } \\
\text { You mean you can do sculpture, poetry, write love stories in } \\
\text { the name of romanticism, then I am sorry this may be culture } \\
\text { but not required in Islam. }\end{array}$ & $\begin{array}{l}\text { Seeing all ethnic, } \\
\text { linguistic and other } \\
\text { basis of identity } \\
\text { except being a } \\
\text { Muslim }\end{array}$ & & \\
\hline $\begin{array}{l}\text { If we do not oppose the wrong sects, they will destroy the true } \\
\text { face of our religion. } \\
\text { I am annoyed at people from other sects because their } \\
\text { practices hurt my religious feelings. } \\
\text { I think members of sects other than mine are followers in } \\
\text { name only as they do not practice the true teachings of our } \\
\text { religion. } \\
\text { Apart from my sect, the religious texts of other sects are not } \\
\text { authentic. } \\
\text { One is not a true Muslim if one respects any religion except } \\
\text { Islam. }\end{array}$ & $\begin{array}{l}\text { Holding one's own } \\
\text { religion/sect as the } \\
\text { only true one, and } \\
\text { negating truth in } \\
\text { others. }\end{array}$ & Intolerance for dissent & \\
\hline
\end{tabular}


Paranoia or Threat perceiving attitude is a general feeling that Islam is in danger and needs to be saved; the feeling that religion is endangered by anything different from one's own worldview. Paranoia involves suspicion of those from another religion and nationality; perceiving spies everywhere; hatred for followers of other religions on the supposition that they are working against Islam; suspicion that progressive nations have made advancements by stealing from Islamic scriptures; wishing for a boycott for some nationalities; thinking that the current plight of Muslims results from a large scale conspiracy against them rather than their own mistakes. Social isolation is its important feature, and fundamentalists tend to shrink in closed circles where identification against the broader social identities is reinforced.

Table 12

Threat Perceiving Attitude: coding levels

\begin{tabular}{|c|c|c|c|}
\hline Raw data & Open/Initial Codes & Selective/Focused codes & Theoretical codes \\
\hline $\begin{array}{l}\text { Our religion is in danger, as there is too much liberalism } \\
\text { spreading around. } \\
\text { Freedom of expression is the biggest threat to Islam. } \\
\text { Most debates on Islam trying to make it more tolerant of } \\
\text { other religions are implanted by enemies. } \\
\text { Western nations are always conspiring against our religion. } \\
\text { Everything eventually goes back to Jews and Hindus. No one } \\
\text { can tolerate Islam. } \\
\text { Suicide attack is not either planned or executed by Muslims. } \\
\text { Only RAW and Israel can do that, not a Muslim. } \\
\text { Who says a single attack was done by Muslim? Not a single } \\
\text { one. All designed by Jews against ummah out of jealousy. } \\
\text { I have authentic sources that XYZ channel giving minorities } \\
\text { too much attention is working for Jews. } \\
\text { It is not difficult to see who is on payroll. Just read his } \\
\text { articles; they will show how much he loves Christians, } \\
\text { favours them in the name of minority rights, how much he } \\
\text { talks about women's rights. What is all this? Conspiracy. } \\
\text { The moment he starts talking about Islam, I know from their } \\
\text { attire that they are going to take your attention away from } \\
\text { modesty and emphasize other things. It is in next two to three } \\
\text { statements that they give that confirm that they are implanted. } \\
\text { Who knows who is implanted; there are too many people } \\
\text { implanted by the West who are here to talk about a liberal } \\
\text { society. Its far better to avoid than to fall a prey to this } \\
\text { allurement carrying away our youth. } \\
\text { All anti-islamic stuff, finding ever new interpretations of } \\
\text { Quran that is not compulsory to cover your head, it is not } \\
\text { compulsory to keep a beard. } \\
\text { I do not read the texts of other sects as I feel afraid that it } \\
\text { would betray me from my faith. } \\
\text { Western models of life exposed through media have put our } \\
\text { religious values in danger. } \\
\text { If we do not boycott western links, it would continue to ruin } \\
\text { our religion. } \\
\text { People wishing to mix up with Christians and Jews want to }\end{array}$ & 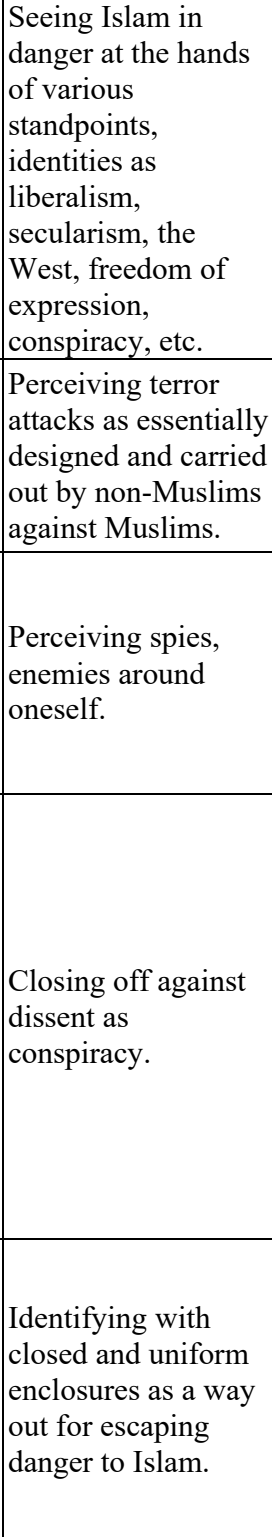 & $\begin{array}{l}\text { Perception of an } \\
\text { impending threat to } \\
\text { one's religion. }\end{array}$ & Paranoia \\
\hline
\end{tabular}




\section{Counter-Narratives to Fundamentalism}

Though expressed by a minority of participants, there were strong counter-narratives to the hyper-exoteric orientation. Rich self-related narratives opened up to the esoteric side reflected as under:

Table 13

Esoteric Orientation: Coding Levels

\begin{tabular}{|c|c|c|c|}
\hline Raw data & Open/Initial Codes & Selective/Focused codes & Theoretical codes \\
\hline $\begin{array}{l}\text { It is simple. All divine orders are always addressed to and } \\
\text { understood, translated and practiced by humans. Now human } \\
\text { beings have a conscience; the divine will is not submitted to } \\
\text { blindly but according to your conscience. Now tell me aren't } \\
\text { there orders that a leader does not actually want you to } \\
\text { obey? Let us take the example where everyone in a team is } \\
\text { hungry and food is scarce. When the meals are available, the } \\
\text { captain asks his team to eat. Now many may eat, but some } \\
\text { using their conscience will not eat. They will ask the captain } \\
\text { that they will not eat while he is hungry. Human conscience is } \\
\text { a refinement that makes you human. } \\
\text { I do not think Quran closes down anything on you. It asks you } \\
\text { to establish justice in society; now it leaves it to your own } \\
\text { decision how to establish justice. It trusts human inquiry, } \\
\text { learning about good political and social systems and } \\
\text { inventions that may make life better. } \\
\text { It is motives that determine what we are and believe me } \\
\text { motives cannot remain hidden no matter how much you paint } \\
\text { and cover them with religion. If our pious people want us to } \\
\text { fight, then they will design and include in religion anything } \\
\text { that suits their motives. So better be careful about why } \\
\text { someone is saying something rather than believing that it } \\
\text { comes from God. Only Quran comes from God and it is open } \\
\text { to everybody. Anyone can read it and understand. }\end{array}$ & $\begin{array}{l}\text { Viewing human } \\
\text { conscience as } \\
\text { pivotal to belief. }\end{array}$ & & Esoteric religiosity \\
\hline $\begin{array}{l}\text { The Holy Prophet ( peace be upon him) said, satan runs like } \\
\text { blood in you. This means rather than finding embodiments of } \\
\text { satan out there, we have to see our own impulses, problems of } \\
\text { impulse control that makes us angry at the slightest } \\
\text { provocation and then blaming some Satan out of ourselves. } \\
\text { It is a belief that Satan is a creation of Allah having a } \\
\text { function in this scheme of things; but we are the best of } \\
\text { creation and more strong than anyone else. I don't think the } \\
\text { Book asks us to wage a war against satan. It is very stupid to } \\
\text { name, blame and curse satan all the time. It is ourselves that } \\
\text { matter. }\end{array}$ & $\begin{array}{l}\text { Thinking of good } \\
\text { and evil } \\
\text { residing in human } \\
\text { beings own } \\
\text { decisions and } \\
\text { actions than satan. }\end{array}$ & & \\
\hline $\begin{array}{l}\text { How can a religion that claims to address the whole humanity } \\
\text { impose one dress on the whole world? use your reason. It is } \\
\text { not possible. I think one reason many scholars are imposing a } \\
\text { certain dress on women especially is just because they want } \\
\text { to impose a certain culture which is not Pakistani or South } \\
\text { Asian at all. } \\
\text { Go back to history of Islam? Did Arabian men and women } \\
\text { leave their particular cultural dress when they become } \\
\text { Muslims? Look at Islamic history in India. Did any of Hindu } \\
\text { woman left wearing a sari or any of her particular dress } \\
\text { when she became a Muslim? Did the prophet ( peace be upon } \\
\text { him) every order you to wear a dress same for all? Does the }\end{array}$ & $\begin{array}{l}\text { Religion not } \\
\text { reduced to outward } \\
\text { norms of piety. }\end{array}$ & $\begin{array}{l}\text { Subjective, } \\
\text { quest oriented religion }\end{array}$ & \\
\hline
\end{tabular}




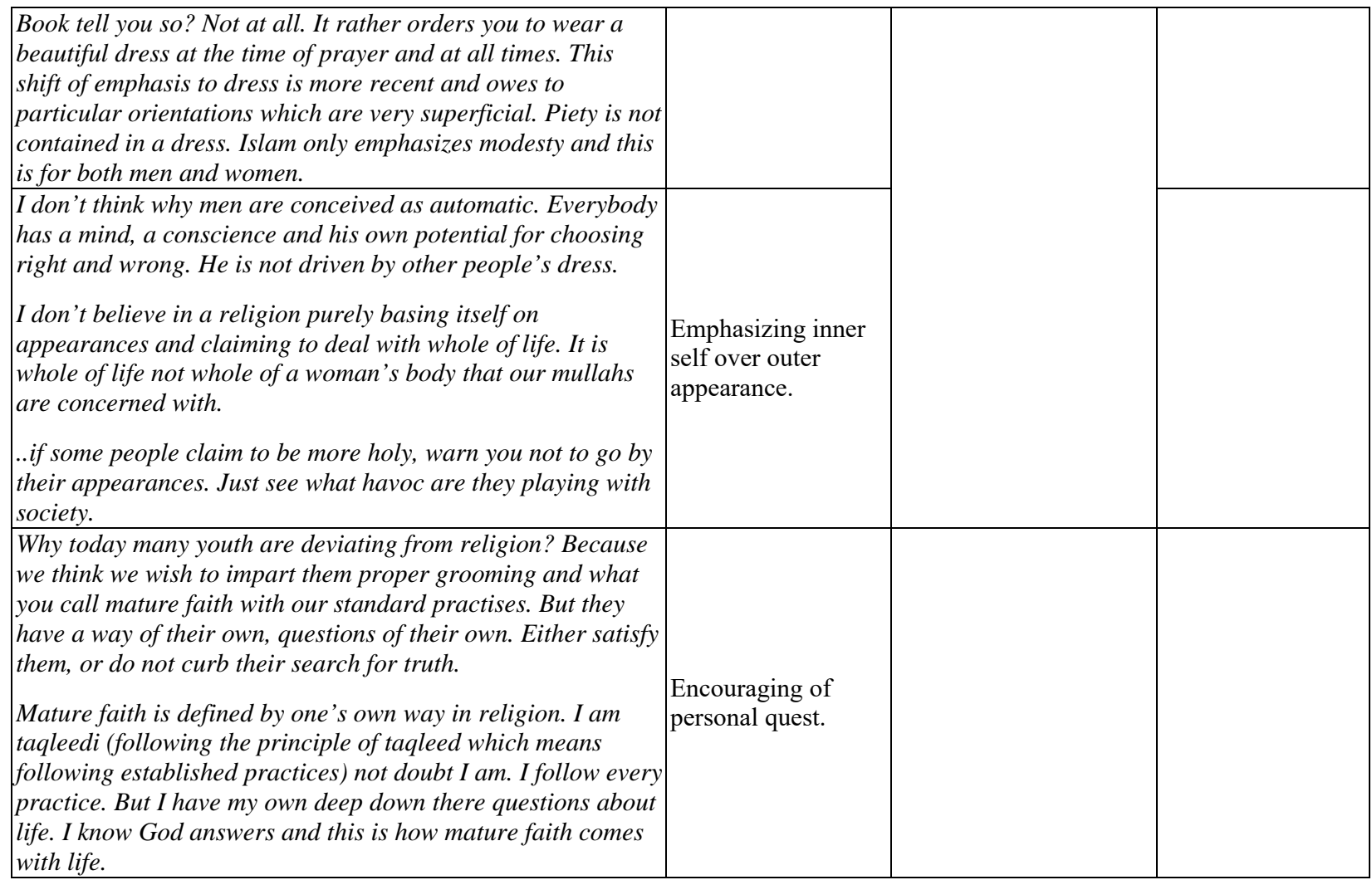

Counter narratives to totalitarianism were found in discourses where a civil society was seen as the aim of Islam than a state per se. Also, a state level Islamic intervention was thought to be non-confined in its political strategy, i.e., any system ensuring social justice was seen as Islamic. Islam was not divorced from politics but political systems seen as cognizant of the need of the times.

Table 14

Islam and Civil Society: Coding levels

\begin{tabular}{|c|c|c|c|}
\hline Raw data & Open/Initial Codes & Selective/Focused codes & Theoretical codes \\
\hline $\begin{array}{l}\text { There could be politics in religion but no religion in politics. } \\
\text { The martyrdom of Imam Hussain was a message for their } \\
\text { makhfee (hidden) khilafah than power oriented goals. This is } \\
\text { where our silsilah becomes very objective though otherwise } \\
\text { we are very individual oriented. } \\
\text { Religion in politics just at the best could mean justice n } \\
\text { honesty. }\end{array}$ & $\begin{array}{l}\text { Religion separate } \\
\text { from politics }\end{array}$ & & \\
\hline $\begin{array}{l}\text { Where things went wrong is our misconception that a state at } \\
\text { war with other states was ever the ideal of Islam in earliest } \\
\text { times. It was a civil society that was set up not a state. State is } \\
\text { oppressive. } \\
\text {...It was to do away with Arab pride not whole of Arab } \\
\text { culture and for that reason any other culture. This is all } \\
\text { Muslims own failure not Islam's; failure that they have shut } \\
\text { themselves in a shuttle and then not ready to see } \\
\text { out of it. I question where is your universality? }\end{array}$ & $\begin{array}{l}\text { Holding that total } \\
\text { state negates claims } \\
\text { of universality }\end{array}$ & & $\begin{array}{l}\text { Islam intending a } \\
\text { civil society than } \\
\text { singular form of } \\
\text { state. }\end{array}$ \\
\hline Going back to past or cherishing it is not a bad symptom. & Tradition to & Islam as an open & \\
\hline
\end{tabular}




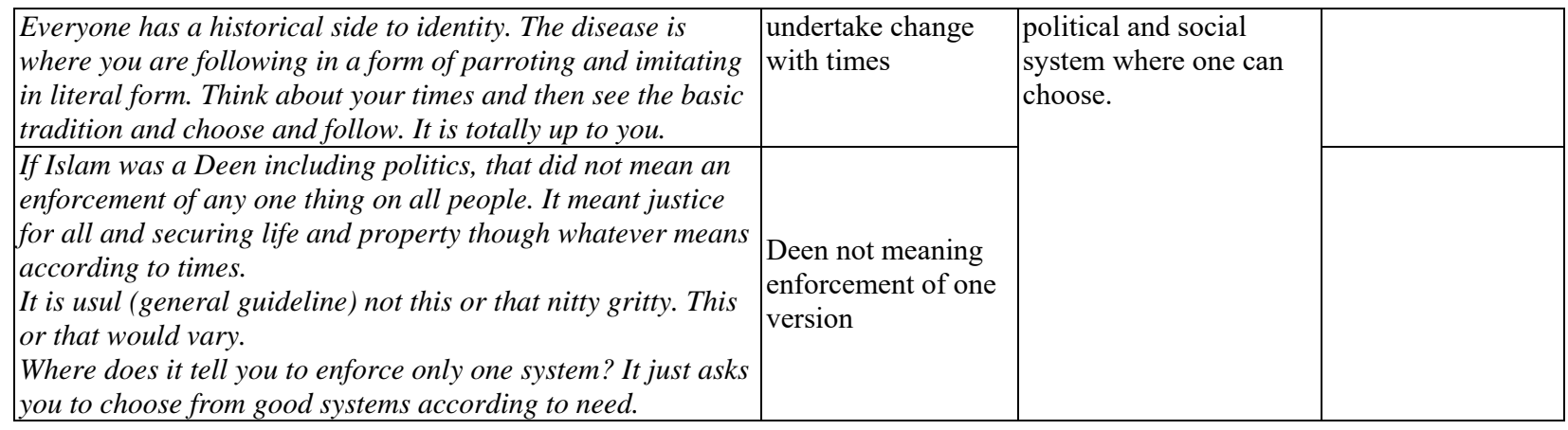

An open minded approach to different other people and different perspectives accompanied certain constructions of Islam. As opposed to a static and closed religion, gaining knowledge and learning from any perspective regardless of Muslim or non-Muslim, was seen as the emphasis of religion. Simultaneously, this opened up debates as freedom to knowledge and freedom to its expression. These perspectives, firstly involved a contextualized thinking where concepts of good and evil were seen in the backdrop of culture they came from. The texts chosen from Quran were those which implied a value relativity as the Quran discusses various nations and people. A sense of ultimate environment or world coherence carried a sense of entering ethical realm as a human need.

Table 15

Open Mindedness: Coding Levels

\begin{tabular}{|c|c|c|c|}
\hline Raw data & Open/Initial Codes & Selective/Focused codes & Theoretical codes \\
\hline $\begin{array}{l}\begin{array}{l}\text { Islam means submission to the Will of Allah. Submission is } \\
\text { there when you know on what principles the nature works? } \\
\text { Your Book instructs you to know and to follow this instruction } \\
\text { is submission. } \\
\text { If the Book asks you to think and reflect, then of course my } \\
\text { belief is that a believer is an inquirer about everything. Why } \\
\text { should believing that Allah created me restrict me from } \\
\text { asking how did the creation come into being? He says, travel, } \\
\text { study and observe how did Allah create? }\end{array}\end{array}$ & $\begin{array}{l}\text { Submission } \\
\text { meaning quest }\end{array}$ & & Open mindedness \\
\hline $\begin{array}{l}\text { If Quran says that human beings are the microcosm of this } \\
\text { universe, then the basic belief is that we have the whole } \\
\text { universe in us. There is no limit to human inquiry and human } \\
\text { potential. How can you know any limit before hand? We have } \\
\text { intellect, we have a spirit, we have emotions, we can even } \\
\text { know the future. } \\
\text { Everyone has a different sort of knowledge to process and } \\
\text { hence a different way to Allah. How does my aunt know in the } \\
\text { morning that today someone will die? She shares her dreams } \\
\text { and the same happens. This means that my knowledge of } \\
\text { science is there but there is another knowledge required to } \\
\text { understand how can she know and tell the future? May be } \\
\text { another world has to be explored. } \\
\text { If your mullahs are telling you not think as it is their } \\
\text { prerogative to think and tell us what to do, then excuse me the } \\
\text { whole Book asks again and again, "Aafalaataqiloon? ("Why } \\
\text { don't they use their reason?)". } \\
\text { The Book trusts human beings that they can use their reason, } \\
\text { gain knowledge and inquire more and more. The universe }\end{array}$ & $\begin{array}{l}\text { Placing trust in } \\
\text { human intelligence } \\
\text { to think about } \\
\text { universe as the } \\
\text { emphasis of Quran }\end{array}$ & $\begin{array}{l}\text { Understanding Islamic } \\
\text { belief as encouraging of } \\
\text { human inquiry. }\end{array}$ & \\
\hline
\end{tabular}




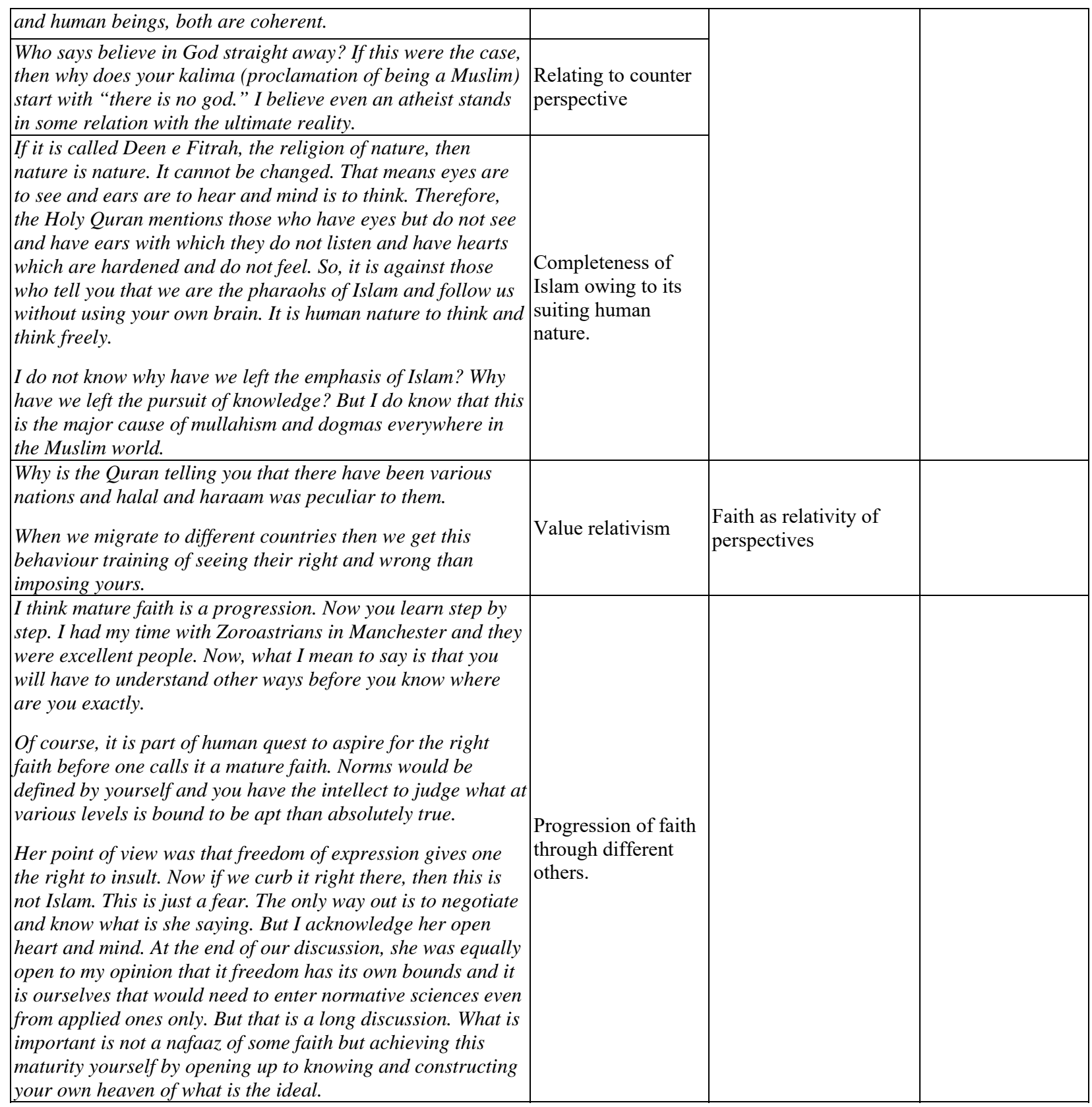

Contextualized thinking was associated with the tolerance of ambiguities on the way and acceptance of human bounds, limitations, imperfections as a believer. Contextualization also involved the awareness of historical evolution and conceptualizations of Islam as they changed over time and that religious tradition is man-made and bound to be varied. Mature faith was constructed as involving awareness of multiplicity of planes of reality.

Table 16

Contextualized Thinking: Coding Levels

\begin{tabular}{|l|l|l|l|}
\hline Raw data & Open/initial codes & Selective/focused codes & Theoretical codes \\
\hline $\begin{array}{l}\text { You mean Muslims did not fight with one another. They did } \\
\text { not kill. Who killed our four righteous caliphs? Christians, }\end{array}$ & $\begin{array}{l}\text { Accepting } \\
\text { controversy as a }\end{array}$ & Locating phenomena in & Contextualized \\
\hline
\end{tabular}




\begin{tabular}{|c|c|c|c|}
\hline Jews or ourselves for the lust of power? & \multirow[b]{2}{*}{ historical fact. } & \multirow{3}{*}{$\begin{array}{l}\text { historical, political and } \\
\text { theological contexts. }\end{array}$} & \multirow[t]{5}{*}{ thinking. } \\
\hline $\begin{array}{l}\text { Yes you can see it openly. There is nothing more vivid than } \\
\text { controversy here amongst us. Muharram starts and one } \\
\text { group stands with placards and banners of hazrat Omar and } \\
\text { the other stands for Ihle bait. They are against each other, } \\
\text { aren't they? I am not saying this is good. I am just saying that } \\
\text { it exists and serves many political functions. } \\
\text { Those who say everything is fine are very dishonest. Now } \\
\text { suppose I don't think everything is fine, then don't I love } \\
\text { Islam? It is just a difference of whether you want to face it or } \\
\text { not. }\end{array}$ & & & \\
\hline $\begin{array}{l}\text { Religion is for humans and practised by humans. This fact } \\
\text { makes it clear that Islam is also taken to our times by } \\
\text { humans. What is wrong with clash? It is like in a family } \\
\text { everyone becomes like the father or mother. No, it is not } \\
\text { possible simply. } \\
\text { Suppose I start with studying Rumi. He would tell you that } \\
\text { God is in you. Then isn't that a controversy? But this is a } \\
\text { controversy that lets you know yourself than falling for just } \\
\text { animalistic life. }\end{array}$ & $\begin{array}{l}\text { Accepting } \\
\text { differences in } \\
\text { religion }\end{array}$ & & \\
\hline $\begin{array}{l}\text { Where there is a craving to know, there is a welcoming for } \\
\text { doubt. If you make doubt your fear, than how can you know? } \\
\text { And at the top of everything we directly attempt at God, as if } \\
\text { God were bound somewhere to be known once for all. He } \\
\text { creates but He gives death and decay. Are't life n death } \\
\text { opposites? }\end{array}$ & $\begin{array}{l}\text { Conviction and } \\
\text { doubt as mutually } \\
\text { reinforcing }\end{array}$ & \multirow{2}{*}{$\begin{array}{l}\text { worldview } \\
\text { incorporating belief and } \\
\text { quest/conviction and } \\
\text { doubt. }\end{array}$} & \\
\hline $\begin{array}{l}\text { Yaqeen (Conviction) is in a spiritual realm. It gives you not a } \\
\text { confinement, but a vision to see vastly. } \\
\text { Belief is not out there in just one way things are. Make sure } \\
\text { that things clash. Only you are real and true and able to } \\
\text { know them in their reality. If everything was plain simple, } \\
\text { then what was the reason God would ask you to make an } \\
\text { effort? }\end{array}$ & $\begin{array}{l}\text { View of conviction } \\
\text { and doubt as } \\
\text { different planes of } \\
\text { reality. }\end{array}$ & & \\
\hline
\end{tabular}

Religious pluralism was generally reflected in tolerant visions, yet the way it was incorporated involved different forms of logic as categorized in Table 5.17.

Table 17

Pluralism: Coding Levels

\begin{tabular}{|l|l|l|l|}
\hline Raw data & Open/initial codes & Selective /focused codes & Theoretical codes \\
\hline $\begin{array}{l}\text { It is said do not leave your religion and do not tease others } \\
\text { religion. If faith is personal, then I would not like something } \\
\text { dearest to me to be offended. So I think for mutual survival } \\
\text { let's not tease others. } \\
\text { The Book says if you call bad names to their god, they will do } \\
\text { the same. }\end{array}$ & $\begin{array}{l}\text { Tolerance for } \\
\text { mutual survival }\end{array}$ & & \\
$\begin{array}{l}\text { What when we are in a minority? Similar things happen. } \\
\text { Would then we not think about what would save us and our } \\
\text { social image? }\end{array}$ & $\begin{array}{l}\text { Pluralism and empathy } \\
\text { as a pragmatist, rational } \\
\text { choice. }\end{array}$ & \\
$\begin{array}{l}\text { As a nation, we'll be at loss. Logical thinking does not } \\
\text { understand why certain people should not be tolerated and } \\
\text { outcast as kafirs. What when we are outcast as Pakis and } \\
\text { other identities? Haven't we spent out lives as a citizen in the } \\
\text { west? }\end{array}$ & Putting oneself in shoes \\
\hline $\begin{array}{l}\text { She was so courageous that she started scolding him for } \\
\text { Shersenting positive }\end{array}$ & Present & \\
\hline
\end{tabular}




\begin{tabular}{|c|c|c|}
\hline $\begin{array}{l}\text { criticism of headscarf even though she was not a Muslim. If } \\
\text { she can understand us, why can't we understand her. } \\
\text { People were so friendly that I utterly forgot what is } \\
\text { discrimination. So what about our country? Why can't we } \\
\text { break this myth of them as bound for hell only? }\end{array}$ & instances & \\
\hline $\begin{array}{l}\text { I think if the whole west were so bad, then why would the } \\
\text { study Islam and convert in large numbers? That means } \\
\text { keeping your eyes and ears open is to be there. Why is it } \\
\text { missing in good believers I met so far? because they think } \\
\text { they are already on the right faith } \\
\text { Not everyone is alike. Choose positive things to look at and } \\
\text { world will not close down onto you by itself. It is our } \\
\text { misfortune that religion has been closed down to us as we } \\
\text { had a second hand knowledge tricking down to us by our } \\
\text { authorities. Look at the west and learn from them how to } \\
\text { question and how to understand answers. }\end{array}$ & $\begin{array}{l}\text { Conversions } \\
\text { indicative of an } \\
\text { open minded west }\end{array}$ & $\begin{array}{l}\text { Pluralism as a response } \\
\text { to good outsiders }\end{array}$ \\
\hline $\begin{array}{l}\text { It is impossible to think of the right and wrong faiths; it is } \\
\text { possible to construe your own faith in relation to the moral } \\
\text { outcome of others' faiths. If this were not the case, then Islam } \\
\text { would not have been telling you in the Quran that heed in } \\
\text { virtues than condemning the different others. It is for your } \\
\text { own maturity. } \\
\text { Other faiths are a part of my faith or at least I can address } \\
\text { them in an unbiased way if I am really a Muslim with mature } \\
\text { faith. }\end{array}$ & $\begin{array}{l}\text { Islam unable to be } \\
\text { understood without } \\
\text { other religions }\end{array}$ & $\begin{array}{l}\text { Pluralism a cognitive } \\
\text { framework to } \\
\text { understand Islam }\end{array}$ \\
\hline $\begin{array}{l}\text { It says it has been said earlier. So it was not re inventing but } \\
\text { re addressing. I don't think many of human beings are really } \\
\text { that outside the circle of Islam as we think them to be. } \\
\text { If you drop one or two clauses here and there, what is the } \\
\text { difference left between Islam and other religions before it. It } \\
\text { is capitulation, not a negation. }\end{array}$ & $\begin{array}{l}\text { Islam as summary } \\
\text { of previous religions }\end{array}$ & \\
\hline $\begin{array}{l}\text { Truth is everywhere as God is everywhere. } \\
\text { It is like different languages can be mutually translated with } \\
\text { certain words requiring more explanation. Faith is like that } \\
\text { and mature faith needs that translation. } \\
\text { All paths lead somewhere. Maturity of faith is not denouncing } \\
\text { but acquiring the truth as Guru Nanak said from anywhere. }\end{array}$ & $\begin{array}{l}\text { Search for shared } \\
\text { meaning }\end{array}$ & \\
\hline $\begin{array}{l}\text { There are times when things seem to break down. Then it is } \\
\text { time to look within yourself for answers. And you do that you } \\
\text { come to know that others have their selves as well. The } \\
\text { Jewish girl whose family was all killed in the holocaust was } \\
\text { also a human being with a self. } \\
\text { I don't think people cry for nothing. It is that the shrine is } \\
\text { their support. I may have my way just that they have theirs. }\end{array}$ & $\begin{array}{l}\text { Personal quest about } \\
\text { truth leading to } \\
\text { empathy }\end{array}$ & $\begin{array}{l}\text { pluralism inspired by } \\
\text { personal quest }\end{array}$ \\
\hline
\end{tabular}

Fundamentalist Islam reflected the above dimensions in an inter-related way. The above themes showed mutually sustaining inter-relationships so that a core model emerged. The answers to the FDI question 'What is your image or model (an idea or a person) of mature faith?' mostly revolved around the same theme of a person or a model who acts on Islam, who is a true Muslim, who is a Momin, and who fulfils what Islam expects from him/her. This led to question of demands Islam places on a Muslim the responses to which led to open ended and exploratory discussions on various facets of Islam. The important pivot of participant led discussions remained Islam and its demands on Muslims in the contemporary world and the resultant injunctions to be followed at individual, social and political levels.

All participants introduced their religion Islam as a Deen_its literal meanings conveyed as a way of life. It 
is introduced in detail as a complete code of conduct in all areas of life. 'Complete' turned out to be a comprehensive code with many connotations attached to it. Figure 5.1how these understandings were encapsulated in certain frameworks. The final model emerging can be described as follows.

\section{Basic Data-Grounded Theoretical Model of Muslim Fundamentalism}

Islam is understood as a totalitarian system subjugating the independence existence of all disciplines and institutions. Since it is complete, it is highly intolerant of diversity and dissent to its own enactment which is essentially a political and state level control. This basic ideological motivation inspiring Muslim religious belief makes it an outward quest against others, highly exoteric in character and power, conquest and victory oriented and necessarily at odds with any other perspective and social system. Since the goal is constructed as holy, all sorts of violent means become rightfully instrumental to the cause. Insofar as the basic frameworks of understanding are power oriented and abusive, authoritarian attitudes are inevitable and reflected in hostile oppression of weaker targets in various venues from family to socio-political spheres. The vision is encapsulated and sustained by particular cognitive orientations as binary vision where ambiguity would be a threat to the strict cognitive boundaries maintaining the worldview. Figure 1 illustrates this model.

All understandings around completeness led to being closed to any new information or perspective, resulting in a myopic vision or closed minded attitude. Islam was thus framed mostly in reference to various collectivities whether concrete embodiments or prevalent social and political discourses as Islam versus the west, Islam versus freedom of expression, khilafah versus democracy, Islam versus cultural practices, etc. The binary thought served to maintain identity salience through exclusions of and competition and conflict with all other ones. Simultaneously, the pure Islamic identity reflected ambiguity intolerance in various forms as overlappings with other religions, controversies in history, and confusions over encounters with new world. Ambiguity, controversy in any form was responded to with a paranoia mainly revolving around the theme of contaminations in pure Islam. Social isolation resulted and fundamentalist response to any broader society is of withdrawing in its own shell and further reinforcing binary categories of non-Islam as a threat to Islamic order. The other was understood in terms of common labels that are fostered and reinforced in closed circles of like minded individuals. Fundamentalists' labelling thus served not only simplified and structured thinking as stereotypes, but also preserving one's own identity against other targets as well as the justification of unequal power relations with targets involved. The cognitive and social-psychological processes involved in fundamentalist orientation thus reinforce one another. 


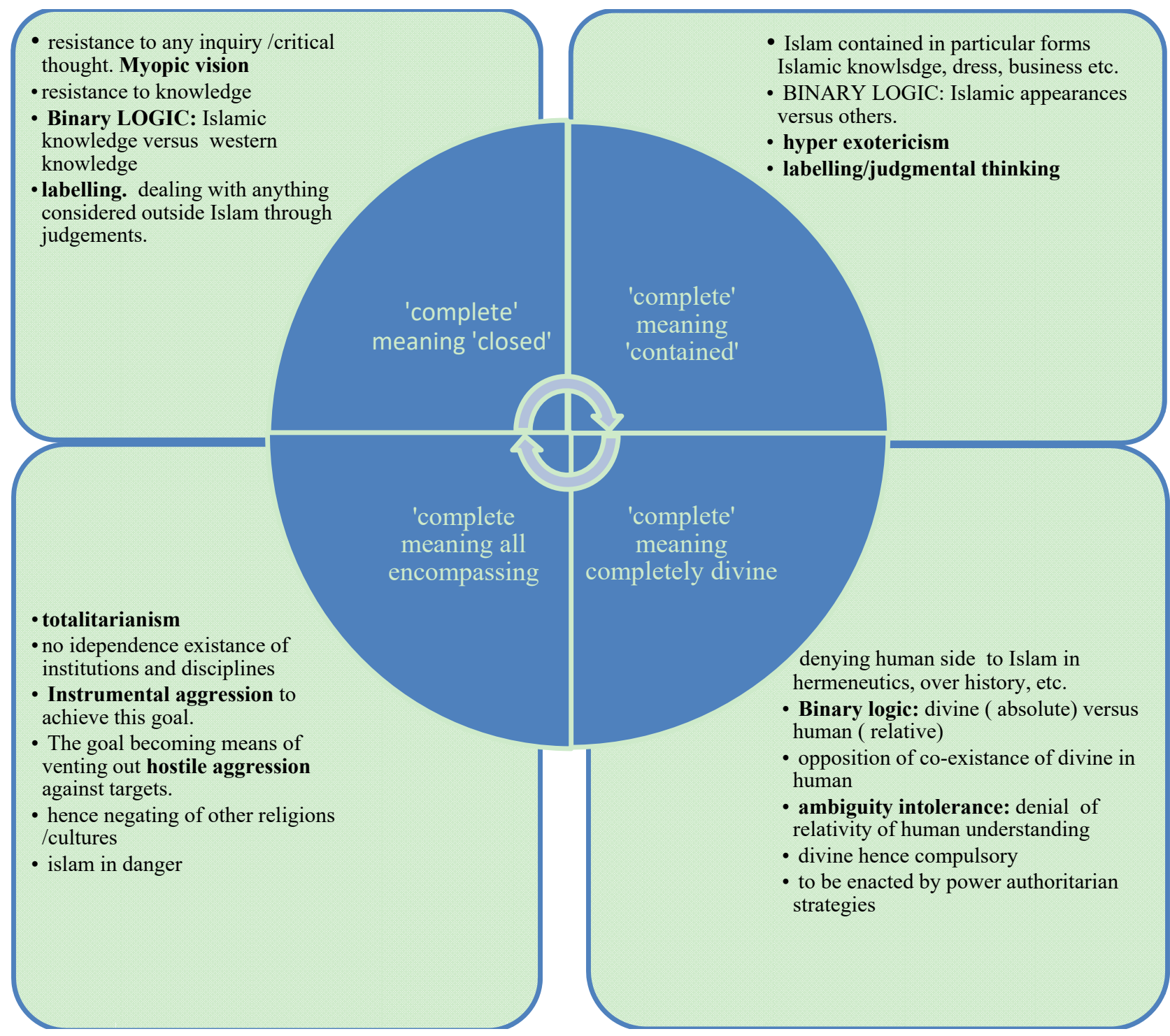

Figure 1. Basic theoretical model of Muslim fundamentalism.

\section{Discussion}

The current grounded theory inquiry revealed the above cognitive and social psychological frameworks constituting Muslim fundamentalism as it is grounded in public understandings and lived experience of religion as well as its counter-narratives. Whereas some factors as revealed by analysis resound with earlier psychological research, others can be helpful in linking psychology of fundamentalism with related research in other disciplines as political science, strategic studies and religious studies thus expanding towards inter-disciplinary perspectives on Muslim fundamentalism.

Fundamentalism, Counter-narratives and Levels of Islam. The study presented various constructions of Islam and what were considered most important values in achieving mature faith. Recent research has argued that particular versions of religion stand as a whole on various levels of faith development. DiPerna (2016) has explored various strands of Islamic tradition with respect to faith and other areas of development. He differentiates some types of Islam along a 'Muslim ladder' of faith maturity as Magic Islam, Mythic Islam, 
Rational Islam, Pluralist Islam and Integral Islam moving occurring from lower to higher stages of faith. DiPerna adds that within each type or step of the ladder, an intensity or altitude exists from moderate to extremist versions.

Magic version concerns rituals, superstitions and charms, ways of warding off black magic and evil influences. Islam at this level is similar to snake handling in Christianity. Many websites concerned with safety from evil influences through rituals support that there is a great public demand for this. At an intuitive-projective faith level, individuals think that their own thoughts can actually control the external events and dismantle evil powers. However, magical Islam is not encouraged by Mythic Islam that bans the use of charms and rituals, with the result that magic forms turn towards acceptable expressions as recitation from the Quranic verses believed to ward off evil and ensure safety. Although magical level of Islam was not a topic of discussion in the current study, warding off evil through Quranic verses called Mauzzaten, or Quls along with other Zikr of other verses for specific purposes is a common practice amongst Muslims of all major affiliations. One can assume that with the widespread practices, Muslims at various stages of faith development otherwise resort to this practice. Thus, magical Islam co-occurs at higher levels owing to its great psychological need.

Extreme versions of mythic Islam are motivated towards their own enforcement; they suppress both the magic form deny the psychological needs of those at this level, as well as the higher forms. According to Di Perna (ibid), Mythic Islam has many expressions primarily in the strict fundamentalist movement of Wahhabism/Salafism. Its moderate forms were by originators as Ibne Wahhab and extreme forms expressed by bin Laden, Al Qaeda and other extremist organizations. Though both are ethnocentric, he distinguishes terrorist from the reformist. The argument that bin Laden's vision is inspired by others as Ibne Tammiyah and Syed Qutb than Ibne Wahhab, however, still leaves the question that regardless of the source of inspiration, both are radical having same philosophy of enacting their version of religion through enforcement and militant strategies. DiPerna holds that today's extremist version of Islam, which is the breeding ground of terrorism results from a perverted picture of reform that originally intended public welfare. The extreme mythic form is obsessed with offensive jihad against Darulharb lands of unbelief, or those without Islamic order, actively pursues martyrdom for this cause, and sees violence and destruction as necessary to meet its ends.

The themes of totalitarianism and closed mindedness support the Mythic Literal conception of Islam. The vision of Islam's opposition to all other systems beyond itself is evident in these themes. The concept of innovation seen in Mythic Literal Islam is also evident from theme diversity intolerance where Islam is conceptualized as reforming any culture it comes in contact with. The concept of innovation in mythic Islam retaliates against all aspects and expressions of cultural life whether local or globally shared. For instance, after the large scale massacre of children of Army Public School Peshawar by the religious extremists in 2014 the foremost concern of fundamentalists was not to burn candles as a memoir as it is an innovation de-shaping Islamic death rituals. Those burning candles were given several labels as 'candle mafia', 'seculars,' etc. Though Mythic Literal Islam aims at going back to original roots of Islam, it reflects a strong Arab cultural ingredient in it.

According to DiPerna (ibid), "Mythic levels of orientation demonstrate several specific characteristics. They cherish structure, authority, and absolute notions of right and wrong. Because the very heart of Islam involves a complete surrender to the will of God, it is unlikely that one still resting at a mythical altitude could find it reasonable to declare any sovereignty as an individual. The individual at mythic levels would prefer external authority to internal decision making." This conceptualization finds referents in the above grounded 
theory model of movement from exoteric to esoteric dimensions offering subjective authority and personal quest over totally external locus of authority and a quest oriented dynamic versus a norm oriented static view of religion. The concept of exotericism as choosing exclusively the separationist behaviors is furthered reinforced by DiPerna's observation that mythic literal Muslims are repelling and exclusivist of different others. The movement from exoteric to esoteric Islam is also obvious in DiPerna's model in terms of shift from external to internal locus of authority, and from exoteric understandings to esoteric meanings. For instance, he holds that whereas all Muslims have no trouble recognizing Christ as a Prophet, the exoteric Muslims "have trouble accepting the experiences like Christ's or the Buddha's causal union (Formless Mysticism) in which Godhead and Self are recognized as one and the same. For the exoteric Muslim population, causal state experiences are one state-stage above their realm of familiarity...Those of Islamic faith who do acknowledge causal state-stages are often drawn to Sufism, Islam's mystic tradition."The absolutist and uncompromising nature of beliefs of reformists does not allow the whole spectrum of Islam to be accessible for one to experience it freely.

Moving up to Islam at next higher stage is what DiPerna holds as rational Islam. Discussing the criticism of rational/moderate Muslims on mythic Islam's negligence of ideas of human rights, tolerance justice and beauty, moderates argue that final authority does reside with Allah, but He has delegated authority to human beings to exercise their free will and bestowed on them capacities as intellect so that they can reason. DiPerna analyses that "This rational interpretation strips away the mythic baggage dependent on external authority, while preserving the credibility of Islam with honor and integrity," moves to post conventional levels of moral development, the focus shifts towards introspective self-criticism and transcendence is from the cycle of self interest of loving Allah for rewards and punishment in return of some absolutist notions of right actions to genuineness and intellectual depth. DiPerna's definition of rational Islam matches with the 'fairness, tolerance and rational choice' by Streib, Hood Jr, and Klein (2010) as a religious style tolerating differences and making rational, fair and just choices with different others.

The next higher level is of Pluralistic Islam advocates a religious consciousness that transcends religious traditions and shows a positive responsiveness towards other faiths, and hold peaceful coexistence as divinely ordained. Reviewing the themes of pluralism, the pragmatist and rational and fair choice elements become evident in the current findings. The increasing openness towards pluralism shows a movement from pragmatism, empathetic stances, positive examplers and to pluralism as necessary for religious and quest oriented frameworks. This corresponds with earlier research by OK (2006) using the last question of FDI concerned with how to resolve religious conflicts. He identified factors shaping up Muslims' perceptions of religious diversity employing the theoretical framework of faith development styles. The first factor involved diversity negativism, belief in a single true version of Islam and effort to convert different others. The current themes of diversity intolerance and closed mindedness to different others involving a preoccupation with one right form of Islam is in consonance with previous research on Muslim samples using faith development paradigm. The next level by OK (ibid) is characterized by conviction of impossibility of change, hence no need to solve incompatibilities and resorting to secularism as a peaceful mutual coexistence strategy. Third factor involved diversity positive attitude with an emphasis on similarities and valuing diversity. The current themes of valuing pluralism in its own right for religious and spiritual quest correspond to this level.

DiPerna highlights the hermeneutics here. For instance, the verse in the Quran "Whosoever desires another din[way of conduct] than Islam, it shall not be accepted of him; in the next world he shall be among the losers." (3:85) is used at mythic literal levels to support ethnocentrism. The same verse at pluralistic levels 
is 'Whosoever desires to behave in any other way than surrendering [to God], it shall not be accepted of him[by God], who will punish the individual by making him among the losers in the world to come," and found in consonance with other verses inspiring the unity of human bondage. The pluralist level uses the word Islam in a rather literal way meaning surrender than in a derivative way suggesting Islam as a particular denomination of people. Pluralist Islam intends to hold multiple perspectives to disclose the complex tapestry of being leading to their inherent unity of Integral Islam advocating a Divine union of creation with God and creation with other creation. To transcend involves inclusion and widening the circle of being.

Fundamentalism: Cognitive, Affective and Behavioural Orientations Supporting earlier research, the personality orientation turned out to be an important contributing factor to fundamentalism in Muslim context. Altemeyer and Hunsberger (1992), Hunsberger (1996) and Wylie and Forest (1992) found authoritarianism at the heart of fundamentalist idealogy. Altemeyer (2003) further differentiated three factors namely conventionalism, aggression and authoritarian submission to constitute authoritarianism. The current findings reflect blind submission to beliefs fostering inequalities and oppression, violent tendencies against weaker targets, and acceptance of conventional religious narratives thus supporting earlier research. McCleary, Quillivan, Foster, and Williams (2011) did a meta-analysis of previous research and found that fundamentalism correlated positively with authoritarianism along with other related factors as ethnocentrism, militarism and prejudice. There is evidence in previous research on authoritarianism being negatively correlated with relativism or the tendency to look at situations with multiple perspectives (McHoskey, 1996) and have been found to lack self sufficiency, imagination and are closed minded (Billigs, Gaustello, \& Rieki, 1993). The current results also highlight that authoritarianism may take on unique cultural expressions. Whereas it generally involves an oppression of weaker targets, misogyny was especially salient in the current contexts. The role of religious texts and indoctrination is important as the current narratives reveal that people refer to religious authorities for justifying authoritarian attitudes. Models of fundamentalism emphasize the role of religious texts in making people authoritarian (Hood, Hill, \& Williamson, 2005). On the other hand, the role of personal meaning making is also crucial as Pakistani culture is mainly a patriarchal one where women assume traditional and subjugating roles.

A consistent relationship exists in earlier research between particular thinking patterns and religious fundamentalism. Altemeyer (2002) finds that fundamentalists are dogmatic. Also, fundamentalists show a need for cognitive closure (Saroglou, 2002). Thus, they avoid complex thinking (Hunsberger, Alisat, Pancer, \& Pratt, 1996). Notwithstanding ambiguity and inconsistency, they resort to firm knowledge structures which can be a way to preserve the closed and structured thought (Jost, Glaser, Kruglanski, \& Sulloway, 2003; Jost et al., 2007). Jost et al. (2003) holds that a fixed religion takes its commandments as given independent of any historical and cultural contexts and contributes towards fundamentalism. This is one reason why fundamentalist surges are seen in times of political uncertainty and upheaval (see Brandt \& Reyna, 2010; Alderdice, 2010). Adam (2007) while analyzing fundamentalism in a cognitive perspective, holds that fundamentalists are not open to assimilation of new knowledge and do not accommodate their previously existing schemas due to their convictions that religious knowledge is perfect and finalized. In this regard, the category of closed mindedness in the current study can be seen as resulting from a highly norm oriented religion. In line with Hood, Hill, and Williamson (2005) who hold that this rigidity comes from an intra-textual approach that holds religious scriptures above all other sources of knowledge, Adam (2007) suggests that "fundamentalists do not grow in their religious development because of particular cultural contents " (p. 10). The current study is one effort to 
analyze these local religious content -process relations hamper religious development beyond fundamentalism. Further work with Muslims living in other countries can be conducted to look into and compare with indigenous contents the beliefs and orientations of Muslims as immigrants and minorities to further generalize upon these categories.

The category Totalitarianism, though not explored in earlier psychological approaches which are individualistic and cognitive, finds referents in recent research bringing together cross-disciplinary evidence from strategic studies, political science, history and theology. Savage (2011), for instance, holds that while a great amount of work in Psychology of Religion has been dedicated to fundamentalism as individual deficiency with personality features as binary thinking, ambiguity intolerance, authoritarianism, dogmatism, etc., fundamentalism and radicalization "arise from more complex shape shifting wholes, rather than properties of deviant individuals” (p. 135). Also, Alderdice (2010) shares, 'I have been struck in my own conversations with religious Islamists how they are keen to emphasize the importance of the political problems rather than religious differences with the West.' Savage (ibid) emphasizes political radicalization as a unique feature of fundamentalist Islam: "This movement is not about conserving a religious tradition, as in Christian fundamentalism. The newer term radicalization better describes this leveraging of change, religious and socio-political-via the selective Islamist narrative-a story that can give direction and meaning to oppressed or marginalized lives." Taylor and Horgan (2002) also point out the interplay of political and economic discontent with the all-embracing nature of Islam to contribute to Islamic fundamentalism which may express as political violence. Discourses on Islam present a yearning for a socio-political change as revealed by the current research. Further work on Islamic fundamentalism can illuminate on this dimension.

Fundamentalism and Faith development theory Grounded theory analysis also links with theoretical paradigms of religious development as faith development theory (Fowler, 1981) that tracks faith development along seven aspects namely social perspective taking ( from ego eccentric to understanding others' perspective), bounds of social awareness ( the broadness of social belongingness for instance from a limited in-group to humanity), form of logic (explanations of events and logic of understanding the world), morality, locus of authority, world coherence (or overall worldview) and symbolic function( understanding of religious symbols). Totalitarianism reflects the power oriented versus negotiation oriented strategies towards conflict resolution with different others as construed in latest developments in faith development paradigm (Keller \& Streib, 2013). The constructions of Islam as nafaaz or enforcement on others of one's own values and the dictatorial control of all social and academic institutions, involves power based strategy informed by narrow bounds of social awareness and a narrow perspective taking where one right answer takes the control of all 'othered' from one's own worldview. Closed mindedness to different others, intolerance for diversity, and constructing different faiths with a paranoid vision also present ego-centric level of development where one does not get beyond one's own perspective. The strategy acquired for dealing with dissent ultimately depends upon the form of logic underlying worldviews. Dichotomizing and essentialist thinking (labelling) as understanding the whole world as Muslim and non Muslim and subsequent intolerance for grey areas constitute fundamentalism.

Fundamentalism and types of religiosity lastly, the theoretical concept of exoteric and esoteric religiosity can be compared with earlier models of religiosity as intrinsic and extrinsic religiosity to shed light on the cross cultural applicability of both. The differentiation of exoteric and esoteric religion is made in religious and theological studies. Kazlev (2009) explains the differentiation as exoteric meaning 'outer' and esoteric as 'inner' religion. Apart from other differentiations, the ones relevant here are esoteric religiosity as sophisticated, 
involving complex thinking, relying on meditative, relying on internalized authority drawing truth from anywhere, transpersonal and aspiring towards universalism. The exoteric is ego-oriented, takes religion as set of beliefs, adheres to external norms and authorities and aspires for simple metaphysical positions. Whilst the exoteric and esoteric can be complementaries, the current analysis reveal fundamentalist orientations to show a hyper-exotericism. The outward and concerned with form-only nature of religion relies on well-defined and clear cut injunctions. The obsession of fundamentalist is thus with the particular act in its form. This explains why they are intolerant of diversity or the notion that other forms of acts may carry religious worth in their own right or may have the same spirit. Obsession with keeping the form of religion intact make extreme exotericism a form of religiosity threatened by different others as well as any ambiguity that would put its unique form amalgamated. The absolutist and uncompromising nature of beliefs of reformists does not allow the whole spectrum of Islam to be accessible for one to experience it freely. The exclusive exoteric orientation can thus be highly separationist and prejudiced and fundamentalists are especially prone to be 'separationist' attitudes against any collectivity they come across. The choice of some exclusionist behaviour amongst varied religious practices is supported by earlier research. For instance, Flere and Levric (2006) found that along with other dimensions where Muslims differ from Christian samples, one is choosing a careful extrinsic personal religiosity instrumentalizing their religion for escaping punishment. Also, they are low in quest and openness to change as compared to Christian samples. Comparing these categories with earlier models of religiosity, the findings of the current study reveal that there is more to religiosity itself than the boundaries of religious and non-religious goals as measured in intrinsic and extrinsic religiosity. For instance, the form of logic involved in exoteric religion stands on purely religious grounds where belief is belief, as well as secular grounds drawing inspiration from rationalist and scientific understandings to fortify religious faith. Its loci of authority can be quite non religious as reason, logic and scientific discourse to prove Islam as well as conventional religious authorities. Since most literature in Psychology concerns with intrinsic and extrinsic religiosity, the esoteric and esoteric differentiation needs to be explored further in cross-cultural samples. Cross-culturally, these differentiations can also be related to what has been termed as 'privatized, experience oriented religion' in studies done in western cultures (Streib \& Hood, 2011). Studies done in western contexts reveal that individuals calling themselves spiritual and not religious have actually left institutional forms for a subjective and experience emphasizing form. Furthermore, the spiritual religion values the inner mystical experience. In highly religious contexts as in the current study, where 'not religious' identification is not common, the need for inward experience oriented religion is nevertheless profound given that institutionalized and normative forms are becoming too rigid to accommodate the individual seeking of the Divine. Further research in other Muslim settings can help in connecting local contexts with mainstream psychological research.

\section{Limitations and Suggestions}

The current study extended its explorations on one question from faith development interview focusing on participants' constructions of mature faith as this fulfilled the objective of getting rich information about local practices and philosophy of Islam. A wholesome approach looking into individual biographical contexts as in faith development paradigm (Keller \& Streib, 2013) can illuminate the paths of religious development that lead to fundamentalist orientations. The research did not relate the results to demographics, in particular, the religious affiliations within Islam. While the only reason was the promise with the participants that their religious affiliations will not be criticized, further research looking into the propensity of particular beliefs with 
fundamentalism can be another project.

\section{Conclusion}

Overall, the study concludes that Muslim fundamentalism constitutes a normative, outward objective authority oriented and static religion controlling collective lives with a uniform vision and exoteric emphasis. Its ideals are to achieve an Islamic State through political mobilisation and revolutionary action. Although fundamentalist discourses are put forward incorporating a variety of interpretations, the basic emphasis remains the same, to 'Islamize' the society around and wage jihad as a way to achieve it. While Islamic fundamentalism has had an active presence in various social and political milieus in Pakistan, studying it in western contexts where Muslims assume minority can further illuminate on the fundamentalist vision of Islam being contaminated and endangered in a global world. Also, an integrative framework incorporating evidence across disciplines can be used to further groom the categories revealed by this study to understand fundamentalism in Muslim contexts.

\section{References}

Adam, R. (2007). Fundamentalism: A Synthesis of Cultural and Cognitive Perspectives. Crossroads: An Interdisciplinary Journal of History, Philosophy, religion and Classics, 1(2), 4-14.

Alderdice, J. L. (2010). On the psychology of religious fundamentalism. In P. J. Verhagen, H. M. Van Praag, J. J. López-Ibor, Jr., J. Cox, D. Moussaoui (Eds.), Religion and psychiatry: Beyond boundaries (pp. 305-317). Chichester, England: Willey Blackwell.

Almond, G., Appleby, R., \& Sivan, E. (2003). Strong Religion: The Rise of Fundamentalism around the World. Chicago U Press.

Altemeyer, B. (2002). Dogmatic behavior among students: Testing a new measure of dogmatism. Journal of Social Psychology, $142,713-721$.

Altemeyer, B. ( 2003). Why do religious fundamentalists tend to be prejudiced? International Journal for the Psychology of Religion, 13, 17-28.

Altemeyer, B., \& Hunsberger, B. (1992). Authoritarianism, religious fundamentalism, quest, and prejudice. The International Journal for the Psychology of Religion, 2(2), 113-133.

Antoun, R. T. (2001). Understanding fundamentalism: Christian, Islamic, and Jewish movements. Walnut Creek, CA: AltaMira.

Billigs, S., Gaustello, S., \& Rieki, M. (1993). A comparative assessment of construct validity of three authoritarian measures. Journal of Research in Personality, 27, 328-48.

Brandt, M. J., \& Reyna, C. (2010). The role of prejudice and the need for closure in religious fundamentalism. Personality and Social Psychology Bulletin, 36,715-725.

Bruce, S. (2000). Fundamentalism. Cambridge: Polity.

Charmaz, K. (2003). Grounded theory. Qualitative psychology: A practical guide to research methods, 81-110.

Charmaz, K. (2006). Constructing grounded theory: A practical guide through qualitative research. Sage Publications Ltd, London.

Corbin, J. M., \& Strauss, A. (1988). Unending work and care: Managing chronic illness at home. Jossey-Bass.

DiPerna, D. (2016). The Muslim Ladder The Infinite Ladder: An Introduction to Integral Religious Studies, Chapter 9. Retrieved from http://www.integralworld.net/diperna03.html

Flere, S. J., \& Lavric, M. (2006). Muslim, Catholic and Orthodox religiosity in Central Europe in contrast to American Protestant religiosity. SOCIOLOGIJA, Vol. XLVII (2005), No. 3.

Fowler, J. (1981). Stages of faith. San Francisco: Harper and Row.

Glaser, B. G. (1978). Theoretical sensitivity: Advances in the methodology of grounded theory. Sociology Press.

Glaser, B. G. (2001). The grounded theory perspective: Conceptualization contrasted with description. Sociology Press.

Glaser, B. G. (2007). Naturalist inquiry and grounded theory. Historical Social Research/Historische Sozialforschung. Supplement, 114-132.

Glaser, B. G. (2012). Stop, Write: B Writing Grounded Theory. Sociology Press.

Glaser, B., \& Strauss, A. (1967). The discovery of grounded theory. London: Weidenfeld and Nicholson, 24(25), 288-304. 
Hogg, M. A. (2004). Uncertainty and extremism: Identification with high entitativity groups under conditions of uncertainty. In V. Yzerbyt, C. M. Judd, and O. Corneille (Eds.), The Psychology of Group Perception: Contributions to the Study of Homogeneity, Entitativity, and Essentialism ( pp. 401-418). Philadelphia: Psychology Press.

Hood, R. W., Hill, P. C., \& Williamson, W. P. (2005). The Psychology of Religious Fundamentalism. New York: The Guilford Press.

Horgan, J., \& Taylor, M. (2002). The psychological and behavioural basis of Islamic fundamentalism. Terrorism and Political Violence, 15(22). 37-71.

Hunsberger, B. (1996). Religious fundamentalism, right-wing authoritarianism, and hostility toward homosexuals in non-Christian religious groups. The International Journal for the Psychology of Religion, 6(1), 39-49.

Hunsberger, B., Alisat, S., Pancer, S. M., \& Pratt, M. (1996). Religious fundamentalism and religious doubts: Content, connections, and complexity of thinking. International Journal for the Psychology of Religion, 6, 201-220.

Jones, M., \& Alony, I. ( 2011). Guiding the use of grounded theory in doctoral studies; An example from Australian film industry. International Journal of Doctoral Studies, vol.6 ( N/A), pp. 95-114.

Jost, L, Conway, L. G., Savage, S.., White, W., \& O’Neill, K. A. (2012). Religious Fundamentalism: An empirically derived Construct and measurement scale. Archive for the Psychology of Religion, 33, 1-25.

Jost, J. T., Glaser, J., Kruglanski, A. W., \& Sulloway, F. J. (2003). Political conservatism as motivated social cognition. Psychological Bulletin, 129, 339-375.

Jost, J. T., Napier, J. L., Thorisdottir, H., Gosling, S. D., Palfai, T., \& Ostafin, B. (2007). Are needs to manage uncertainty and threat associated with political conservatism or ideological extremity? Personality and Social Psychology Bulletin, 33, 989-1007.

Kazlev, M. A. (2009). Exoteric and esoteric. Retrieved from http://www.kheper.net/topics/esotericism/esoteric_and_exoteric.htm

Keller, B., \& Streib, H. (2013). Faith development, religious styles and biographical narratives: Methodological perspectives. Journal of Empirical Theology, 26(1), 1-21.

Martin, P. Y., \& Turner, B. A. (1986). Grounded theory and organizational research. The journal of applied behavioural science, 22(2), 141-157.

Marty, M. E., \& Appleby, R. S. (Eds.). (1991). Fundamentalisms Observed. Chicago: University of Chicago Press.

McCleary, D. F., Quillivan, C. C., Foster, L. N., \& Williams, R. L. (2011). Meta-Analysis of Correlational Relationships Between Perspectives of Truth in Religion and Major Psychological Constructs. Psychology of Religion and Spirituality, 3(3), 163-180. doi:10.1037/a0022208

McHoskey, J. (1996). Authoritarianism and ethical ideology. Journal of Social Psychology, 136, 709-717.

Patton, M. Q. (2002). Two decades of developments in qualitative inquiry a personal, experiential perspective. Qualitative social work, 1(3), 261-283.

Riesebrodt, M. (1993). [1990]. Pious Passion: The Emergence of Modern Fundamentalism in the United States and Iran. Berkeley: Univ. Calif. Press.

Saroglou, V. (2002). Religion and the five factors of personality: A meta-analytic review. Personality and individual differences, $32(1), 15-25$.

Sbaraini, A., Carter, S. M., Evans, R. W., \& Blinkhorn, A. (2011). How to do a grounded theory study: a worked example of a study of dental practices. BMC medical research methodology, 11(1), 1.

Strauss, A., \& Corbin, J. (1990). Basics of qualitative research. Newbury Park: Sage.

Streib, H., \& Hood, R. W. (2011). Spirituality' as privatized experience-oriented religion: Empirical and conceptual perspectives. Implicit Religion, 14(4), 433-453.

Streib, H., Hood Jr, R. W., \& Klein, C. (2010). The religious schema scale: Construction and initial validation of a quantitative measure for religious styles. The International Journal for the Psychology of Religion, 20(3), 151-172.

Wylie, L., \& Forest, J. (1992). Religious fundamentalism, right-wing authoritarianism and prejudice. Psychological reports, 71(3 suppl), 1291-1298. 